The Effect of Integrating Music Listening With an Attachment- And Affective-Focused

\title{
The Effect of Integrating Music Listening With an Attachment- And Affective-Focused Short-Term Psychotherapy in an Individual With Relational Trauma: The Case of "James"
}

\author{
G. PAUL BLIMLING ${ }^{a, b, c}$
}

\author{
${ }^{a}$ Department of Psychiatry, Albany Medical College/Albany Medical Center, Albany, NY \\ ${ }^{\mathrm{b}}$ Correspondence regarding this article should be sent to G. Paul Blimling, Albany Medical Center \\ Department of Psychiatry, 25 Hackett Blvd, Albany, NY 12208 \\ Email: blimlig@amc.edu \\ ${ }^{\mathrm{c}}$ Note: This article is a reformatted and edited version of my dissertation (Blimling, 2015). \\ Editor's Note: G. Paul Blimling, PsyD., is a 2015 clinical psychology graduate of the Graduate School of Applied \\ and Professional Psychology at Rutgers University. He currently holds the position of Assistant Professor of \\ Psychiatry at the Albany Medical College/Albany Medical Center in Albany, NY. In addition to his clinical work in \\ the faculty practice, he teaches and supervises medical students and psychiatry residents. His work is heavily \\ influenced by short-term dynamic therapy models, and he continues to enthusiastically integrate music into his \\ clinical practice.
}

\begin{abstract}
The purpose of this study is to explore the utility and feasibility of incorporating client-chosen music listening into a short-term dynamic therapy model in an individual with trauma. Specifically, Diana Fosha's Accelerated Experiential Dynamic Psychotherapy (AEDP) was chosen due to its focus on emotional experience and attachment. Relevant literature regarding the current clinical applications of music is presented, along with research supporting music's effects on relevant psychotherapeutic mechanisms such as affect, autobiographical memory, and attachment. These effects are illustrated through the use of the hybrid case example of "James," a composite psychotherapy client who struggles with symptoms stemming from relational trauma. In addition to being informed by clinical examples in relevant psychological literature, James' case is assembled from actual psychotherapy cases of the author. Demonstrating this client's course of treatment provides an avenue for describing key clinical issues related to the utility of music within a more traditional short-term dynamic therapy model. By adopting a qualitative, disciplined inquiry approach, treatment is tailored to the client's unique psychological struggles within the context of historical, contextual, and relational factors. Following a pragmatic case study research format (Fishman, 2005), case material is analyzed both qualitatively and quantitatively. Discussion explores how an integrative treatment approach, exemplified in the case of James, can effectively combine psychodynamic, relational, and musical elements in treating individuals with relational trauma and the resulting pathology. James' case is designed to be a resource for therapists who seek to gain additional understanding of a new component in providing effective and meaningful treatment for individuals with relational trauma.
\end{abstract}

Key words: music listening; music \& psychotherapy; music and emotions; experiential therapy; trauma treatment; AEDP; metaprocessing; therapist presence; psychotherapy integration; case study; clinical case study 
The Effect of Integrating Music Listening With an Attachment- And Affective-Focused

Short-Term Psychotherapy in an Individual With Relational Trauma: The Case of "James" G.P. Blimling

Pragmatic Case Studies in Psychotherapy, http://pcsp.libraries.rutgers.edu

Volume 15, Module 2, Article 1, pp. 116-166, 07-10-19 [copyright by author]

\section{CASE CONTEXT AND METHOD}

\section{Rationale for Choosing This Client}

In June of 2011, shortly following my first year of graduate school, I was asked to begin work with a non-profit called Music for all Seasons. My role was described as that of a "psychology mentor" for their new program called Voices of Valor, an eight-week program for recently returned veterans from Iraq and Afghanistan that utilized music as a means of selfexpression and reintegration into civilian life. I was chosen in large part due to my background as a classically trained cellist, which has informed my interest in the combination of music and psychotherapy in the treatment of individuals with past trauma, as well as other clinical diagnoses. In the context of the group, my responsibilities included co-facilitating the group meetings, administering feedback measures, and assisting with selection of group members, however one particular aspect of my role within the group intrigued me from the very beginning. As part of the curriculum developed by myself and the administrators of the program, I asked the veterans to bring in music that was personally meaningful and expressive for them, which was to be listened to collectively in the following meeting. The results of this musical sharing were remarkable; members of the group recounted memories of loved ones, friends, and significant people in their lives. Further, they discussed how the music made them feel, how it fit into their identity, and how their experience related to those around them. I began to realize that music is an extraordinarily powerful means of accessing difficult or painful affect, prompting the recall of important memories, and of facilitating bonding among the group members. This experience has led me to pursue the development of a model of psychotherapy which draws upon these facilitative aspects of music in the treatment of trauma and other complex clinical presentations.

The following is an examination of how such a model would be implemented; the client discussed is a hybridized composite of a number of individuals, however the format of the dissertation will follow the traditional pragmatic case study design. This will include a detailed discussion of the client and the setting in which treatment was provided, a review of the extant research that has informed the development of the proposed treatment, the guiding conceptualization on which the implementation of the proposed treatment is based, a thorough conceptualization of the case and description of therapy process and outcome, as well as discussion of the limitations of the study and potential directions for future research.

In order to fully explore the utility and multifaceted nature of the proposed treatment, the characteristics included in the case of "James" are heavily drawn from my own experience, particularly with regard to the individuals in the aforementioned veterans' groups, clients seen through the clinic discussed below, and representative cases discussed in the extant literature regarding the use of music in psychotherapy.

\section{The Clinical Setting in Which the Case Took Place}

James was seen through a state-funded outpatient day program in Brooklyn, New York. The clinic offered a wide range of services, including individual and group psychotherapy, medication management, and occupational services and skills training. 
The Effect of Integrating Music Listening With an Attachment- And Affective-Focused

Short-Term Psychotherapy in an Individual With Relational Trauma: The Case of "James" G.P. Blimling

Pragmatic Case Studies in Psychotherapy, http://pcsp.libraries.rutgers.edu

Volume 15, Module 2, Article 1, pp. 116-166, 07-10-19 [copyright by author]

This setting was chosen in particular due to its emphasis on creative therapies, specifically on music and music therapy as a mechanism of change. The clinic employed two music therapists, individual music therapy and numerous music therapy groups, as well as a full band comprised of clients that performs both at the clinic and at various venues across the city. This creative atmosphere and established utilization of music as part of the therapeutic model employed by the clinic made it a natural setting in which to utilize the presently proposed treatment model.

James' treatment lasted approximately 32 weeks and was understood to be time-limited due to the therapist's status as a student and resulting one-year affiliation with the clinic. James was not charged for services received at the clinic (as the setting was state-funded), which included weekly individual psychotherapy and monthly medication management. Throughout his treatment the therapist was supervised by a licensed psychologist and also consulted with the clinic's music therapists and with the well-known psychodynamic clinician and scholar Nancy McWilliams, through her weekly supervision group.

\section{Sources of Data Available Concerning the Client}

Prior to beginning treatment, I had access to both the basic phone screening form that was completed prior to James' first appointment, as well as the formal intake interview that was completed by another clinician in the setting. Intakes in this setting may or may not be completed by the treating clinician; in this case the intake interview was completed by a senior psychologist and the case was referred to me for treatment.

James had received no prior mental health treatment, and collateral information from other sources was not sought.

\section{Confidentiality}

Given that James is not an actual person but rather an amalgamation of many different individuals, the confidential information supplied by those persons is protected. Where necessary and appropriate, details have been further disguised or fictionalized to provide additional protection for those on whom the hybridized case is based. The conversations quoted herein are reproduced from actual conversations across numerous settings, and session content may be abridged to focus upon the most relevant material.

\section{THE CLIENT}

James is a 52 year old Caucasian male seeking treatment for the first time. James was self-referred to treatment following a falling-out with his family following the death of his only sister of a suspected brain aneurism approximately one year prior. James met the DSM-IV criteria for major depression, endorsing low-mood, fatigue, apathy, decreased appetite, insomnia, difficulty concentrating, and occasional passive suicidality. These recurrent major depressive episodes were reported to have occurred throughout the entirety of James' life for as long as he can remember. Further, James reported numerous past traumas, which were mostly relational in 
The Effect of Integrating Music Listening With an Attachment- And Affective-Focused

Short-Term Psychotherapy in an Individual With Relational Trauma: The Case of "James" G.P. Blimling

Pragmatic Case Studies in Psychotherapy, http://pcsp.libraries.rutgers.edu

Volume 15, Module 2, Article 1, pp. 116-166, 07-10-19 [copyright by author]

nature and the resulting symptoms did not meet DSM-IV criteria for PTSD. Additionally, James was diagnosed with personality disorder NOS, exhibiting pervasive paranoia and suspicion across multiple domains, emotional reactivity that often led to sudden, explosive outbursts of anger, and a general instability and tumultuousness in his interpersonal relationships. Finally, James reported intermittent periods of alcohol abuse and dependence, some severe, stating that he was aware of his tendency to "numb out" and "self-medicate" using alcohol.

\section{GUIDING CONCEPTION, WITH RESEARCH AND CLINICAL EXPERIENCE SUPPORT}

Much has been written regarding the relationship between music and various core aspects of human experience, including language, affect, and memory. Anthropologists have never discovered a civilization that did not possess some form of music (Patel, 2010), which suggests that there is a ubiquity in human beings' desire and ability to connect with musical expression. This presumed ubiquity is foundational to the guiding conception and the rationale for the inclusion of music in psychotherapeutic intervention with a range of clinical presentations. Numerous prominent writers and thinkers have attempted to decipher how this enduring relationship with music was developed, and for what purpose. While there is still debate surrounding this issue, one prominent position regarding the origins and purpose of music lies in the intonated preverbal communication between mother and infant (Trevarthen \& Malloch, 2002). This is to say that the most basic form of music exists in the so-called "motherese," which has been found to exist across all cultures, in which mothers instinctively utilize this highlyintonated speech to facilitate attachment with their infants (Trevarthen \& Malloch, 2002). In fact, research indicates that music can serve as an important facilitator of social bonding later in life as well, with particular types of music having the capacity to reflect and communicate the values that individuals hold (Boer, Fischer, Strack, Bond, Lo, \& Lam, 2011), thus allowing for a means of self-identifying and establishing a connection with others. Punk music, for example, is often associated with a broader culture that extends beyond the music itself to include specific values and reflections of personal and collective identity. This relational and self-defining aspect of music is central to its utility within psychotherapeutic practice.

In addition to the prominent relational and social aspects of music, researchers have investigated a link between music and memory. A study by Janata, Tomic, and Rakowski (2007) found that music has the power to elicit salient autobiographical memories from an individual's past, which they have termed Music Evoked Autobiographical Memories (MEAMs). These findings are corroborated by neurological research which has found that the sensory experience of music is tied to the activation of the limbic system, specifically the hippocampus, and encoded into long-term memory in much the same way as smell (Swallow, 2002). This is also to say that, given the disposition to remember and encode highly emotionally arousing events and stimuli, it follows that music's ability to evoke such emotional responses would cause it to be easily encoded as part of those memories. In fact, music is already being used as part of "reminiscence therapy" for individuals with Alzheimer's and dementia in order to facilitate the recall of autobiographical memory (Woods et al., 2005). 
The Effect of Integrating Music Listening With an Attachment- And Affective-Focused

Short-Term Psychotherapy in an Individual With Relational Trauma: The Case of "James" G.P. Blimling

Pragmatic Case Studies in Psychotherapy, http://pcsp.libraries.rutgers.edu

Volume 15, Module 2, Article 1, pp. 116-166, 07-10-19 [copyright by author]

\section{Current Applications of Music}

At this point it is important to differentiate the presently proposed method from existing applications of music, both clinical and non-clinical. Given the innate nature of our relationship with music and its multifaceted influence over us, it is unsurprising that many have turned their attention to the more utilitarian ways in which it can be applied. The influence of music has been applied to everything from controlling vandalism and influencing consumer behavior to treating the motor and cognitive impairments in Parkinson's and Alzheimer's patients (Sacks, 2008; Wilson, 2002). With regard to treating various psychiatric diagnoses, the field of music therapy has been prolific in its widespread clinical use of music, which has been used to treat anxiety, depression, post- traumatic stress disorder, among others (American Music Therapy Association, 2013). Music therapists particularly utilize music's ability to influence mood and to express salient or difficult emotions. Many music therapy techniques often involve the use of therapistchosen music and the collaborative production of music, either through composition or improvisation. These techniques include Guided Imagery with Music (GIM), music relaxation, and the use of various musical instruments to tap into and express emotion (Bruscia, 1998).

However, the topic of this paper draws upon one particular concept from the literature on music therapy, which has been termed "song communication" (Bruscia, 1998). Song communication consists of either the therapist or client choosing a particular song deemed relevant to the therapeutic issue that is listened to collaboratively and processed in the session. Topics discussed may include the meaning of the lyrics, what the song represents to the individual, and how it may represent a type of emotional communication that transcends words. The present paper focuses specifically on the use of client-chosen music as a complementary aspect of an affective- and attachment- focused dynamic psychotherapy.

\section{Levels of Music Use within Psychotherapy}

It is important, then, to differentiate the use of music in psychotherapy from the practice of music therapy. Bruscia (1998) delineates 4 levels of music inclusion in what he calls "music psychotherapy". These 4 levels differ by the degree to which music as seen as the therapeutic element or germane to the therapeutic issue. The first, which he terms "music as psychotherapy," involves the exclusive use of music production or listening as the therapeutic mechanism, with no need for verbal discourse. The second level, "music-centered psychotherapy," again utilizes music as the therapeutic mechanism, with verbal discourse only serving to guide, interpret, or consolidate the musical experience. The third level, "music in psychotherapy," utilizes both music and verbal discourse equally as means of accessing the therapeutic issue. Finally, the fourth and most relevant level to the topic of this paper is "verbal psychotherapy with music." This approach does not view music as a therapeutic mechanism, but rather as an ancillary but facilitative aspect within more traditional psychotherapy. As such, the use of client-chosen music to augment a more traditional psychotherapy fits nicely within this fourth level. 
The Effect of Integrating Music Listening With an Attachment- And Affective-Focused

Short-Term Psychotherapy in an Individual With Relational Trauma: The Case of "James" G.P. Blimling

Pragmatic Case Studies in Psychotherapy, http://pcsp.libraries.rutgers.edu

Volume 15, Module 2, Article 1, pp. 116-166, 07-10-19 [copyright by author]

\section{Music in Psychotherapy}

Some clinicians have already begun to incorporate client-chosen music into their practice in this way. For example, Mary Butterton (1998) writes of her treatment of a patient named Liz, whom she invited to bring in music that Liz felt would help her to communicate her emotions and experiences in the session. Butterton draws upon the work of Malloch and Trevarthen (2002), specifically the idea of "communicative musicality," which is rooted in the preverbal communication between mother and infant. This preverbal communication, sometimes called "mother-ese," is the highly intonated vocalizations that mothers use to communicate and establish joint attention with their infants. This pattern is universal and cross-cultural: "whether in Scotland, Nigeria, Germany, Sweden, or Japan, researchers found that mothers spoke to infants with similar rhythms and intonation, and infants moved in sympathy" (Malloch \& Trevarthen, 2009, p. 2). This, argues Butterton, is why the inclusion of music within psychotherapy assists with establishing a meaningful connection with the client (i.e., attachment), as well as helping to uncover relevant memories and experiences. Butterton (2008) writes:

The shared experience of listening to music, followed by the patient's descriptions of the experience of listening to music, may be seen to assist the process of psychotherapy, especially when this process reaches an impasse and words are no longer available to the patient. In these circumstances, music is a medium and a means of right-brain-to-right- brain communication to the therapist; what the patient needs to have the therapist know and feel. It would seem that aspects of some patients' inner states are held in their choice of music. In the conversation following the shared experience, the patient will usually attempt to verbalize or "say more" about the shared experience and this may be communicated in part by gesture, liveliness (or not) of the body, in other words, their "communicative musicality" (pp. 2-3).

Butterton's emphasis on music's ability to promote attachment, evoke meaningful memories, and to facilitate the here-and-now experience of affect lends itself nicely to the work of Diana Fosha, who has developed a short-term dynamic psychotherapy model called Accelerated Experiential Dynamic Psychotherapy (Fosha, 2000). In fact, Butterton's description of collaborative music listening in therapy as "right-brain to right-brain" communication strongly resonates with Diana Fosha's statement that this right-brain to right-brain communication "constitutes the stuff of therapy" (Fosha, 2010, p.45).

Fosha argues that the basic causes of psychopathology can be directly traced to the individual's ability to deal with their core affective experience while maintaining a connection to others (Fosha, 2000). Fosha defines the concept of core affect, writing that it constitutes "our emotional responses when we do not try to mask, block, distort, or severely mute them" (Fosha, 2010). Fosha asserts that individuals utilize defenses that attempt to block this painful core affect, but that these simultaneously perpetuate destabilizing "signal affects." Thus, therapy is directed at utilizing the therapeutic relationship to foster reparative emotional experiences. To this end, Fosha emphasizes the importance of emotional experience in the presence of a trusted other (the therapist) in the process of psychotherapy. Fosha contrasts the different ways of being in two triangles, one called the "Triangle of Defensive Response," which illustrates how defense- 
The Effect of Integrating Music Listening With an Attachment- And Affective-Focused

Short-Term Psychotherapy in an Individual With Relational Trauma: The Case of "James" G.P. Blimling

Pragmatic Case Studies in Psychotherapy, http://pcsp.libraries.rutgers.edu

Volume 15, Module 2, Article 1, pp. 116-166, 07-10-19 [copyright by author]

driven functioning blocks core affect, and the other the "Triangle of Expressive Response," which illustrates "hope-driven" functioning and easier access to authentic affect and adaptive responses (Fosha, 2010). This approach is largely based on the work of Bowlby (1982) and his examination of attachment styles between infants and their caregivers. Fosha relates these past patterns to current styles of affective regulation and interpersonal functioning, specifying four basic levels of attachment-based affective competence.

The first and most ideal style she calls "feeling and dealing while relating," which is reflective of a secure attachment style. This indicates that the individual has the ability to process painful affects without resorting to defensive structures which then trigger "signal affects" such as anxiety, shame, and depression. This allows the individual to maintain a more stable and relationally functional sense of self in the face of difficult affect, and is the result of attuned and affectively competent caregiving.

The second style Fosha calls "feeling but not dealing." which corresponds with an insecure-preoccupied attachment style. In this style, the individual often feels overwhelmed by painful affect and has difficulty with self-modulation such that they are unable to effectively process and cope with the distressing affect. This often leads the individual to feel anxious and destabilized, contributing to interpersonal problems and affective interference with regard to handling obligations and maintaining relationships. This is the result of a caregiver who has had difficulty modulating their own affective experience, thus rendering them unable to help the child regulate their own distressing affect.

The third style Fosha terms "dealing but not feeling," which corresponds to the insecuredismissing attachment style. This style is characterized by a distancing from emotion due to internalized convictions that emotional experiences may be shameful, worthless, or irrelevant. This often leads to difficulty with intimate interpersonal relationships, as well as defensive structures that utilize considerable ego resources to maintain this distance from core affective experience. This is often the result of a caregiver who defensively minimizes interpersonal relationships and affective experience in order to maintain composure, giving the child a sense that expressing affect, particularly difficult affect, holds the potential to cause abandonment or ruin the critical relationship. The final style Fosha calls "not feeling and not dealing," which is reflective of a disorganized attachment style. In this style, the trauma of loss from ineffective and incoherent parenting instills the individual with fear and a sense of being alone (Fosha, 2010).

These styles, especially the middle two, are particularly relevant in treating survivors of trauma. These individuals often experience painfully overpowering and potentially incapacitating emotions ("feeling but not dealing"), or conversely utilize defensive structures that attempt to maintain distance from these painful emotions ("dealing but not feeling"), with both resulting in functional and interpersonal difficulty and maintenance of the negative "signal affects." Ideally, the individual will gain from AEDP a sense of secure attachment to the therapist, which will in turn allow for here- and-now emotional experience and instill a sense of affective competence and confidence that difficult emotions can be effectively processed without the threat of loss of the attachment figure. This, in turn, allows the individual to be more genuine in their ability to relate to others, and greatly diminishes the need for defensive structures that maintain disruptive 
The Effect of Integrating Music Listening With an Attachment- And Affective-Focused

Short-Term Psychotherapy in an Individual With Relational Trauma: The Case of "James" G.P. Blimling

Pragmatic Case Studies in Psychotherapy, http://pcsp.libraries.rutgers.edu

Volume 15, Module 2, Article 1, pp. 116-166, 07-10-19 [copyright by author]

"signal affect." Fosha herself writes:

People disconnect from their emotional experience, afraid of being overwhelmed, humiliated, or revealed as inadequate by the force of feelings, only to pay the price later in depression, isolation, and anxiety. If affect-laden experiences can be made less frightening in the therapeutic environment - that is, if patients can be helped to feel safe enough to feelthen they can reap profound benefits, for within core affective states are powerful adaptive forces and processes with tremendous therapeutic potential (Fosha, 2000, chapter 1, paragraph 3).

\section{Guiding Conception and Rationale for Music/AEDP Model}

Given the research that supports music's ability to universally facilitate elicitation and expression of affect, promote attachment and social bonding, and to elicit salient autobiographical memories, as well as the substantial overlap of the emphasis on affective experience and attachment that is shared by both Butterton and Fosha, it is hereby proposed that the inclusion of a client-chosen music listening component in combination with AEDP will yield positive outcomes for individuals with trauma and affective dysregulation. This is to say that the early (and potentially continued) use of client-chosen music in the therapy will facilitate attachment with the therapist in individuals with trauma, and in turn, allow them to safely experience and subsequently process affect that may have been previously overwhelming. Further, it is hypothesized that the use of music as a secondary mode of affective communication will facilitate and enhance verbal processing of past traumatic events. Finally, it is hypothesized that music will facilitate the recall of salient autobiographical memories that will further augment the traditional AEDP approach.

\section{ASSESSMENT OF THE CLIENT'S PRESENTING PROBLEMS, GOALS, STRENGTHS, AND HISTORY}

\section{Presenting Problems}

James is a 52 year old Caucasian man living alone in Brooklyn, New York. James presented for treatment at the request of his niece, who told him that she would no longer speak to him until he sought therapy. This followed the sudden and unexpected death of James' older sister approximately one year prior from a suspected brain aneurism. James reports that his brother-in-law informed him that his sister "Janice" (55) had passed away with a brief phone call, stating simply that "she's gone" before hanging up. James tried to call back multiple times without success, when finally his brother-in-law answered the phone and told him not to call again and "to allow his family to mourn in peace." James reports that he was enraged by this rebuke and began drinking heavily, leading him to call back and leave aggressive, threatening messages on their answering machine. James reported not remembering the specifics of what he said, but did say that he had "said some really nasty things." As a result, his niece threatened to cut off all contact until he had sought therapy. 
The Effect of Integrating Music Listening With an Attachment- And Affective-Focused

Short-Term Psychotherapy in an Individual With Relational Trauma: The Case of "James" G.P. Blimling

Pragmatic Case Studies in Psychotherapy, http://pcsp.libraries.rutgers.edu

Volume 15, Module 2, Article 1, pp. 116-166, 07-10-19 [copyright by author]

James reported on and off major depressive episodes for his entire life, stating that he sometimes felt as though he had "just drawn a bad hand." James reported that he felt increasingly isolated, often not leaving his apartment for days at a time. This had strained his relationships with friends, who James felt were "ducking out" of their friendships with him. Further, James reported numerous pressing medical issues, including recently diagnosed atrial fibrillation and high blood pressure. These issues necessitated frequent visits to doctors, which caused tremendous stress and irritability for James, who reported frequent altercations with care providers. James further reported past periods of alcohol abuse, acknowledging that he was "numbing out" in order to avoid the difficult emotions evoked by his life circumstances. At the time therapy began, James denied drinking more than "a couple beers or glasses of wine" per week. Prior to the intake interview, I had no prior information about James except for a very basic phone screening sheet, which included a brief statement of the presenting problem as well as contact information.

\section{Quantitative Assessment}

In order to track changes in symptoms over time, James was administered two psychometrically sound quantitative measures on a bi-monthly basis, as per the policy of the treating clinic. These included the Depression Anxiety Stress Scale (DASS) and the Outcome Questionnaire-45 (OQ45). These were administered prior to the session and included as part of James' clinic records. As treatment was psychodynamically oriented, these results were not overtly included in the treatment itself. However, they did prove to be informative and reflective of James' overall trajectory while in therapy, and they serve to further contextualize and establish the proposed treatment.

The Depression Anxiety Stress Scale (DASS) is a 42-item questionnaire consisting of three self-report scales designed to measure the negative emotional states of depression, anxiety, and stress (Anthony, Beiling, Cox, Enns, \& Swinson, 1998). Each of the three scales contains 14 items, divided into subscales of 2-5 items with similar content, which are designed to measure the three related negative emotional states of depression, anxiety, and tension/stress. James' DASS scores, as well as the corresponding $\mathrm{Z}$ scores, can be found in Table 1.

Also administered was the OQ-45, a 45-item self-report measure that consists of a total score and three subscale scores: Symptom Distress, Interpersonal Relations, and Social Role (Lambert, Burlingame, Umphress, Hansen, Vermeersch, Clouse, \& Yanchar, 1996). James' OQ-45 results can be found in Table 2.

\section{Relevant Personal History}

James grew up in a small town in Michigan in an extremely unstable home. James reports conflict between his parents from as early as he can remember; his father was a hard-drinking worker at one of the automotive plants in the area and his mother, while unemployed, was often away from home. James reports substantial and violent conflict in the household that resulted in a separation of his parents when he was very young, approximately three or four years of age. James stated that after the separation he lived with his mother and often visited his father. James 
The Effect of Integrating Music Listening With an Attachment- And Affective-Focused

Short-Term Psychotherapy in an Individual With Relational Trauma: The Case of "James" G.P. Blimling

Pragmatic Case Studies in Psychotherapy, http://pcsp.libraries.rutgers.edu

Volume 15, Module 2, Article 1, pp. 116-166, 07-10-19 [copyright by author]

reports that, following the separation, his mother became involved with a number of different men, which later led James to conclude that she was a prostitute. Further, James' mother would leave him unattended for long periods of time, occasionally returning home intoxicated and abusive. On a number of occasions, James' mother struck him with various household items such as hangers and spatulas, sometimes resulting in the need for medical care. Further, James described a number of incidents which suggest that his mother may have exhibited some borderline and histrionic traits. These include sudden and intense anger, jealousy, and subversion of his attempts to visit his father, as well as feigning strokes and other medical emergencies after abusing James in order to instill guilt and maintain proximity ("Look what you made me do, you're giving me a stroke and I'm going to die!").

James' father also offered little emotional protection to James. During one visit with his father when he was approximately 5 years of age, James reported that his father asked where his mother and one of her male visitors were. James stated that he knew their location, and so his father put him in the car and they drove to the house together. At that time, James and his father walked in to find his mother having sex with a strange man, at which point his father picked James up and threw him onto the bed, saying "take your bastard child back" before exiting and speeding off. James reports having spent the remainder of the night in a seedy bar with his mother, as she was afraid to return home. Despite the abuse present in his relationships with both of his parents, James reported feeling substantially closer to his father, overwhelmingly preferring to stay with him rather than his mother. This was only one of many traumatic memories recalled by James with regard to his childhood and chaotic relationship with his parents.

James reported that the following year his older sister had gone to live with a distant relative, who had agreed to take in only her, leaving James in the house with his mother. James reports that while they were not physically raised together after that time, he went to great lengths to stay in touch with her and to maintain contact via phone and mail, sometimes having packages sent to friends' homes to prevent them from being intercepted or destroyed. James later described his sister as his "most important relationship" and a source of great support, and so was devastated to learn of her sudden death.

When James was sixteen, he reported a severe and violent altercation with his mother's boyfriend. He reports that the man was an alcoholic and "a hitter", often flying into rages suddenly and without provocation. Following the scuffle, James ran away from home and acquired a small studio apartment, stating that he needed to leave or he "would've killed that man". James was able to secure employment as a stocker in a grocery store, completed high school, and enrolled in a local community college as an English major. Following that, he moved to Brooklyn, New York and secured a position as a copy editor, which he did for many years before retiring due to physical disability. James was never married and reported only a few transient romantic relationships.

\section{Presentation at the Beginning of Therapy}

This was James' first experience in therapy. From the first session, James was distrustful 
The Effect of Integrating Music Listening With an Attachment- And Affective-Focused

Short-Term Psychotherapy in an Individual With Relational Trauma: The Case of "James"

\section{G.P. Blimling}

Pragmatic Case Studies in Psychotherapy, http://pcsp.libraries.rutgers.edu

Volume 15, Module 2, Article 1, pp. 116-166, 07-10-19 [copyright by author]

and derogatory towards the therapist and vehemently denied needing therapy, stating that he only sought treatment due to an ultimatum by his niece, with whom he felt he had been close. James repeatedly asked for a therapist that was "not a kid" (26 at that time) and became angry when informed that, due to clinic limitations and therapist availability, he would have to remain in treatment with me. James further insisted that he was "not a crazy person" and displayed extreme irritability during the initial interview and initial sessions, often chiding the therapist for asking "stupid questions," especially with regard to past relationships. Despite the initial difficulties, James agreed to commit to four sessions and to reevaluate subsequently.

Despite his irritability and confrontational disposition, James was intelligent and articulate, often drawing upon his large vocabulary. Further, he displayed an encyclopedic knowledge of literature, languages, and music, often referencing both classic and obscure works of literature in session. While it was apparent that his knowledge of music was equally extensive and varied, James later reported that he had not listened to music in many years because of his fear that it would be too emotionally overwhelming to do so.

\section{Diagnosis}

James' official diagnosis, summarized in Table 3, included the following: Major Depressive Disorder, Severe, Recurrent; R/O Post-Traumatic Stress Disorder; Alcohol Abuse, In Partial Remission; Personality Disorder NOS; R/O Borderline Personality Disorder; and R/O Narcissistic Personality Disorder.

\section{Strengths}

James' most pronounced strength was his intelligence; he exhibited an ability to discuss and understand abstract concepts and ideas, as well as having a large amount of knowledge and experience upon which to draw. Despite some substantial initial difficulty, James would later prove to be dedicated to his attendance in therapy and committed to the work.

\section{CASE FORMULATION}

\section{Autonomous Ego Functions}

James' ego functioning was compromised due to the syntonic nature of his symptoms and his extreme difficulty regulating difficult affect without becoming overwhelmed. He demonstrated little insight into the origin of his difficulties and often exhibited poor reality testing in his understanding of the motivations of others. However, he displayed no cognitive, linguistic, or motoric functioning, and he demonstrated above- average intelligence. He initially had great difficulty establishing rapport, but was increasingly invested in the therapy and connected to the therapist as the therapy progressed.

\section{Affects, Drives, and Defenses}

James demonstrated an extremely narrow range of affect, with most complex and 
The Effect of Integrating Music Listening With an Attachment- And Affective-Focused

Short-Term Psychotherapy in an Individual With Relational Trauma: The Case of "James" G.P. Blimling

Pragmatic Case Studies in Psychotherapy, http://pcsp.libraries.rutgers.edu

Volume 15, Module 2, Article 1, pp. 116-166, 07-10-19 [copyright by author]

difficult feelings subsumed under anger. Further, he showed great difficulty tolerating this anger without externalizing and lashing out at others, which had negatively impacted numerous areas of his life. When alone, which was how James spent the majority of his time, the anger was internalized and directed at the self, resulting in severe depression and extremely low selfesteem. James was further very counter-dependent and uncomfortable in dependent relationships, such as with healthcare providers and with his sister's family. James utilized more primitive defenses in order to manage his intense affective experience and sense of powerlessness, including projection, primitive withdrawal, projective identification, and primitive devaluation. These allowed him to externalize and to attribute maliciousness or incompetence to those around him, resulting in the more tolerable and empowering feelings of anger and rage rather than the more painful feelings of desperation or sadness.

\section{Object-Related Functions}

James' stance with regard to the objects that populate his experience reflect the chaotic nature of his childhood as well as his deeply felt wish for intimate interpersonal contact. James is often unable to realistically interpret the motivations and intentions of others, instead attributing them to that person's innate "badness." This is especially true when James is dependent upon those individuals, such as in his emotional dependence on his sister's family and his physical dependence on his doctors ("The doctors are complete f-ing idiots," "my brother-in-law is just an asshole"). This sense of dependence on others likely evokes many of his feelings of childhood dependence and powerlessness, resulting in an overwhelming affective experience that is manifested as anger. This pattern remains fairly consistent across James' interpersonal world, with the exception of his late sister, whom James had regarded as completely trustworthy and "good."

\section{Self-Related Functions}

James' sense of self appeared to be fragile and largely fragmented, as exhibited by his extreme susceptibility to precipitous drops in self-esteem. Further, James often experiences himself as isolated and indignant in his righteousness, oscillating widely between feeling his own worthlessness and feeling as though it is everyone else who is worthless. This instability in James' sense of self has made it all but impossible for him to maintain trusting, intimate relationships with others.

\section{Dynamic Features of Personality}

James' substantial history of abuse and neglect, the event of his sister's death and subsequent rejection by her family, and the acute stress presented by his pressing medical issues all figure into James' clinical presentation and present dysphoria. From an early age, James was exposed the harshness of the world with little protection from his parents. This included exposure to graphic sexuality, violence, and substance abuse from his mother and an overall pattern of neglect and manipulation by his father. This early exposure and the dysfunctional, chaotic, and unpredictable interpersonal relationships with his parents led James to develop a disorganized attachment style that has substantially contributed to his difficulty developing 
The Effect of Integrating Music Listening With an Attachment- And Affective-Focused

Short-Term Psychotherapy in an Individual With Relational Trauma: The Case of "James" G.P. Blimling

Pragmatic Case Studies in Psychotherapy, http://pcsp.libraries.rutgers.edu

Volume 15, Module 2, Article 1, pp. 116-166, 07-10-19 [copyright by author]

trusting, intimate relationships.

Further, James often utilized more primitive defenses, such as projection, projective identification, and primitive devaluation, suggesting a borderline level of functioning. This defensive constellation often manifested in overt hostility and aggression towards those on whom James felt dependent, which likely reflected feelings towards his parents which were experienced as dangerous and which he was unable to express as a child. This anger in dependent relationships is manifested in his reaction to rejection by his sister's family and frequent altercations with various healthcare providers. This pattern further demonstrates an extremely narrow range of affect, with most negative emotions subsumed under anger or rage with little capacity for self-reflection and reflective-ego functions. This was further evidenced by James' initial hostility towards the therapist and the relatively long period required to establish the therapeutic alliance.

In keeping with the foundational concepts of the AEDP model set forth by Fosha (2000), a central goal of the therapy was to create a holding environment in which James could experience authentic affect, without becoming overly defended, within a trusting therapeutic relationship. This experiencing and processing of painful affect while maintaining a connection to the therapist allows for the innate self-righting tendencies to take hold, providing James with a reparative emotional experience and increased capacity for intimacy with others. It is hypothesized that James' irritability and hostility have led him to become more socially isolated, thus feeding his depression.

Further, this tendency to become angry is rooted in James' childhood experiences of the world and of intimate relationships, which must also be addressed to foster his ability to form and maintain these social connections. In order to facilitate such authentic experience and affective contact, the use of James' own recorded music selections was introduced. This was hypothesized to augment the experiential and affective emphasis of AEDP by providing a medium which was able to bypass defensive structures and allow a more direct route to the hereand-now experience of affect.

\section{COURSE OF TREATMENT}

\section{Sessions 1-4: Lean on Me-Establishing Rapport, Overcoming Resistance, Introducing Music, and Gathering Additional Data}

My initial goal, as with any client, is to establish good rapport and a sense of mutual collaboration for the benefit of that client. Further, I orient the client to therapy and my individual style while creating an environment where all thoughts and feelings are welcomed. I accomplish this through an engaged curiosity with regard to the client - their expectations or experiences with therapy, what they hope to accomplish, what has brought them to my office in the first place. James' initial defendedness, his propensity to viciously devalue others, and the almost tangible sense of intense anger in the room made this a particularly challenging phase of treatment. 
The Effect of Integrating Music Listening With an Attachment- And Affective-Focused

Short-Term Psychotherapy in an Individual With Relational Trauma: The Case of "James" G.P. Blimling

Pragmatic Case Studies in Psychotherapy, http://pcsp.libraries.rutgers.edu

Volume 15, Module 2, Article 1, pp. 116-166, 07-10-19 [copyright by author]

Upon James' first visit to my office, it was apparent that establishing rapport and "buyin" to the process of therapy would be a difficult task. James took a seat on the couch opposite me and his irritation at being there became immediately apparent; "What are you," he asked, "like 18? And why are you the one that's seeing me-last week I saw Dr. R." I explained to James that I was a pre-doctoral psychology extern, and that the case had been assigned to me by Dr. R, who would also serve as my direct supervisor for the case. "Well, no offense, but I don't think you know shit. First of all, I don't even need to be here-the only reason I even came back is because my niece won't speak to me until I saw somebody, which is bullshit anyway because I'm not crazy and I don't need this." I reassured James that I did not feel that he was "crazy" and suggested that, since he had made the choice to come in, perhaps we could find a way to use the time productively. I hypothesized, albeit early on, that these initial derogatory comments were likely characteristic of James' defensive style, which was to feel anger in situations in which he felt he had no control. In fact, James' anger had been noted in the intake as the overwhelming affect, though punctuated by a few moments of self-deprecating humor.

Further, the felt accusation that he was "crazy" was intolerable for him, and so he felt an overwhelming need to distance himself as much as possible from the concept.

James then went on to inform me that he was certain he would not be returning to therapy, given my obvious inexperience and lack of credentials. I reassured him that, ultimately, the decision was his as to whether or not to return, but given that he had already presented to the appointment, perhaps we could find something constructive to discuss in our brief time together. James then told me the story of his sister's passing and his subsequent difficulties - he had been close with her, and following her sudden and unexpected death, he was told by his brother-in-law not to contact him or his daughter (James' niece) and to "let them mourn in peace." Even from the first meeting, it was evident that James carried a great deal of pain as a result of this exclusion and isolation. He reported that he became enraged and began to drink heavily, apparently calling and leaving "really nasty messages" on their answering machine. James was subsequently contacted by his niece and informed that she would no longer have any contact whatsoever with him until he sought treatment. This, James informed me, was the reason he was sitting in my office today; not because he felt any need to resolve issues related to loss, grief, or his often indiscriminate anger, but rather as a condition to maintain the last fragile relationships he had left. James left my office at the end of the hour with a sarcastic "thanks doc" and another reassurance that he would not return, despite my own reassurance that I would leave the hour open for him should he change his mind.

I was informed at the staff meeting later in the week that James had called a number of times, each time trying to coerce the person at the front desk to transfer his case to a "real doctor," despite continued assertions that he did not actually need treatment. James was informed, much to his chagrin, that he would have to remain in treatment with me due to limited clinician availability.

James did not present for his second session. I followed up with a phone call during the allotted hour in which James told me that he did not feel like talking to "a kid" who clearly would not understand his experience. I understood that this to be a precarious moment for James; 
The Effect of Integrating Music Listening With an Attachment- And Affective-Focused

Short-Term Psychotherapy in an Individual With Relational Trauma: The Case of "James" G.P. Blimling

Pragmatic Case Studies in Psychotherapy, http://pcsp.libraries.rutgers.edu

Volume 15, Module 2, Article 1, pp. 116-166, 07-10-19 [copyright by author]

James had become almost totally isolated, had a history of substance abuse, and was facing serious medical problems. Further, he was being given the message that he was a burden on his family and felt he had been accused of being a "crazy person," and I had serious concern that his intense aggression may turn inward and result in a suicide attempt or completion, given that occasional suicidal ideation had been noted in his intake. My handling of the situation could impact whether he returned to therapy or fled. I told James that I understood his concern - after all, I did look young, and what reason did he have to trust me with his difficult story and inner experience? I noted, however, that a big part of my job was to help him to help me understand what things were like for him, despite our differences, which included more than age. I proposed that we agree to a full four sessions - if he did not feel he could trust me after four sessions, I would do everything I could to find him another clinician to see. James reluctantly agreed, and we scheduled for the following week.

Given James' defensiveness and suspiciousness regarding therapy, I felt that an alternate route into understanding his experience was necessary. I could not simply ask James about his feelings, as this would no doubt activate his defenses and likely cause him to become angry and dismissive, especially given his sensitivity regarding the felt accusation of being "crazy." Instead, I hypothesized that perhaps we could find another way to build trust, to find out more about his experience, and perhaps even to begin talking about his feelings. As discussed in the first chapter of this paper, music has been shown to be an effective "right-brain-to-right-brain" method of communication, and one which both the literature and my own experience had shown to be an effective way of bypassing strong defenses. After consulting with both my supervisor and the music therapists at the clinic, it was agreed that my inclusion of music listening with James fell within the usual best practice standards at the clinic, and I was cleared to suggest it as an addition to our treatment as usual.

James presented to our second meeting twenty minutes late. Rather than confront James on this, as I often did with other patients, I instead expressed that I was glad he had returned to see me. James took a seat on the couch and hunched over, gazing at the floor. "Don't be flattered," I was told. James asserted that he would simply "ride out" the last three sessions until, as per our agreement, I would find him a "real doctor." I acknowledged that this had been our agreement. "So what now?", asked James. I told James we could discuss anything that was on his mind; it was his session to use however he wished. "But you want me to talk about my feelings, don't you? Forget that, I don't have to explain anything to you, and this is only temporary anyway." I acknowledged that it must be difficult to discuss these things with me, especially given that he did not want to be there. I told him that I had an idea, and if he was willing maybe we could try it.

I asked James if he liked music, to which he replied "among other things, yes. I like a lot of art." I followed up by saying, "I'm wondering if, next time, you might be willing to bring in some music that's important to you. You can tell me a little about what it means to you and why you like it. It's totally your decision, what do you think?" James, somewhat to my surprise, was agreeable to the idea. "Does it have to be anything in particular?", he asked. I responded that it could be anything he liked. James told me that, perhaps, at least then we could have some "interesting discussions" until his ultimate transfer to another clinician. James left my office deep 
The Effect of Integrating Music Listening With an Attachment- And Affective-Focused

Short-Term Psychotherapy in an Individual With Relational Trauma: The Case of "James" G.P. Blimling

Pragmatic Case Studies in Psychotherapy, http://pcsp.libraries.rutgers.edu

Volume 15, Module 2, Article 1, pp. 116-166, 07-10-19 [copyright by author]

in thought about what he might bring.

James presented on time for our third session carrying a CD. I had set up a stereo with a $\mathrm{CD}$ and tape player in preparation for our session. After an initial greeting, James presented me with an album by Bill Withers called Still Bill. I thanked him for remembering to bring something to share with me. "You're not gonna analyze me, are you?", asked James. I told him that my intention was not to analyze him in the classical sense, but rather to get a better idea of who he was and what was important to him.

Without saying anything, he handed me the CD and told me it was the fifth track, a wellknown song called Lean on Me. As we listened together, James sat with his arms crossed in his lap, looking down at the floor. The song's full lyrics are listed in the Appendix.

We sat in silence for several moments after listening to the song, and James remained slumped over looking at the floor. "What does that song mean to you?", I asked gently. "My sister," he said. We sat in silence for several moments. "It reminds me of my sister." Several more moments of silence. "I remember when I was 10 Janice was able to sneak out of our Aunt's house and take a bus to come see me." James' voice had cracked, his voice softened. He sat with his arms folded, head in his lap and face obscured. "I had a tree fort that I had built on a vacant lot where I kept a flashlight, a radio, some canned food and other things. I went there when my mother came home drunk or I knew she was gonna hit me, it was my only real refuge. We went there together and after we talked for awhile we just sat and listened to the radio. I remember this song came on and we just looked at each other. Janice told me that, even though we lived apart, she would always be my sister and I could always count on her."

James sat up and looked at me, his eyes glassy. "That's a very moving story," I said, "I can tell how important your sister was to you." James' face tightened. "You wanna make some big deal outta this now, right?", James said, his defensive mechanisms triggered by this brief moment of vulnerability. Within Fosha's AEDP framework, this is defined as a "signal affect" which serves a defensive purpose, and allows the individual to distance themselves from their core affect. I told James that I had no agenda but to better understand where he was coming from. We spent the remainder of the session in the usual back-and-forth, with James asserting the he needed no treatment and me being cautious not to confront him in any way that may cause him to shut me out completely and flee from treatment. When I informed James that we were out of time for the week, he curtly said "They pay you to sit here and chat about music with people all day? Must be great gig for you, but if I have to be here I'm not gonna spend my time talking music with a kid." I told him that was fine, but that I hoped he would stick to the agreement we had made. "Do I have to pick more music for your playlist?", he asked. I told him no, I just hoped he would be coming back to see me the following week. "Sure thing, doc," he said sarcastically as he left.

The next week, somewhat to my surprise, James was right on time. Before he had even sat down on my couch, he informed me that he had been thinking a lot since our last session. "Oh really?", I asked. "What about?" He said that after leaving, he had begun remembering things that he had not previously been able to remember, such as the contents of some of the 
The Effect of Integrating Music Listening With an Attachment- And Affective-Focused

Short-Term Psychotherapy in an Individual With Relational Trauma: The Case of "James" G.P. Blimling

Pragmatic Case Studies in Psychotherapy, http://pcsp.libraries.rutgers.edu

Volume 15, Module 2, Article 1, pp. 116-166, 07-10-19 [copyright by author]

letters he had received from his sister and their plans to meet up and leave the state of Michigan behind them forever. I reflected to James that it certainly did sound like he had been thinking a lot. "I hadn't listened to that song in a long time," he said. "What was it like for you to hear it again?", I asked. "Oh here we go with the feelings again, what's with you?" he said. I told James that I had not, in fact, asked him anything about how it made him feel, but rather what it was like for him. "But," I added, "I would imagine it made you feel something. It certainly did for me when I listened to it and heard your story." James was silent for a long period, looking at me as if he were sizing me up. "I mean, I didn't have like, a breakdown or anything," he said. "So what, then?", I asked. "I mean, I had forgotten how important my sister was to me then. It was like she was the one who was gonna save me, look after me or something, I dunno...”.

James trailed off. I waited several moments before responding, "Like I said last time, it's clear how important your sister was to you. I'm so sorry for your loss." James, again looking down, began to wipe his eyes. We sat in silence for a long time before he said anything. "I can't believe she's gone. Just like that, gone." I nodded as James continued to cry quietly. Again, James was allowing himself to experience the painful core affect he had worked so hard to avoid, but we were running out of time. I gently informed James that we would soon have to stop for the day. "It's been four sessions," I said, "what do you want to do next?" James looked at me and said, "I guess we could keep talking. I mean, I just don't want to have to start this story all over again," he said. I told him I was glad he had decided to stick it out with me. "For now," he qualified. We agreed to continue meeting weekly. "Thanks, doc," he said on his way out, this time with only the slightest hint of sarcasm.

Up until this point, my main goal had been to keep James in treatment. It was apparent to me that he was struggling mightily with the death of his sister, but that his primary feelings of grief and sadness were manifested as signal affects of anger and hostility. These protected him from feeling vulnerable or dependent on others, which he had not previously been able to be with anyone but his late sister. Guided by Fosha's AEDP model, I saw my objective as being to make the space safe enough for James to experience his core affect (Fosha, 2010) without manipulation or distortion from his defensive structures, thus allowing for a new interpersonal experience and his innate "self-righting tendencies" (Fosha 2010) to take hold. James had only just touched the surface of his immense grief and sense of isolation from the death of his sister in his initial sessions with me, and the inclusion of collaborative music listening had provided a conduit through which James' formidable defenses could be bypassed, however briefly. Further, it helped James and I to establish rapport for him to "show me" a part of his experience, especially given that it was so difficult for him to describe that experience in words. As therapy progressed, it was hoped that James could continue to have contact with his difficult core affect such that he could meaningfully process his grief while gaining a new interpersonal experience of trust.

\section{Sessions 5-12: The Death of Falstaff_Processing Anger, Loss, and Grief}

In the following sessions, James reported that his angry outbursts had become more frequent. In session number five, James reported that he had been escorted out of a hospital waiting room due to an aggressive outburst resulting from a long waiting time. Frustrated and 
The Effect of Integrating Music Listening With an Attachment- And Affective-Focused

Short-Term Psychotherapy in an Individual With Relational Trauma: The Case of "James" G.P. Blimling

Pragmatic Case Studies in Psychotherapy, http://pcsp.libraries.rutgers.edu

Volume 15, Module 2, Article 1, pp. 116-166, 07-10-19 [copyright by author]

tired, James began to badger the attending nurse who, understandably, became frightened of James. Security was called and James was escorted off the premises with a request never to return. "They're all idiots," James would report, "those doctors don't give a shit about anything but money." I reflected to James that it sounded like his anger might have gotten the best of him that time. "Yeah, but what the fuck do you care? You're one of 'em, taking your paycheck and running." I took the opportunity to inform James that I was not, in fact, paid for my work, but that was likewise beside the point.

James' anger in the following session (\#6) had increased substantially as well- - he would come in, seething about one event or another, only to direct his anger at me for being likewise incompetent, uncaring, or flippant. Recent sessions with James had become like walking a minefield, and any efforts to confront his anger or its antecedents rarely resulted in productive work. Similarly, any attempt to return to the moment of vulnerability James felt while listening to the Bill Withers song with me were even more harshly rebuked as trivial nonsense or psychological quackery. I felt myself running out of options to help James to return to that undefended state, and the intensity of James' anger was again putting him at risk for serious physical or legal consequences, and so I suggested in the $7^{\text {th }}$ session that James once again bring in music that was meaningful for him. James was enraged, "You're still on that?!", he bellowed, "I don't know what you think you're doing, but I'm getting the fuck out of here," he said as he left my office 20 minutes early.

I was deeply troubled and concerned for James - the intensity of his emotions was apparent, and he possessed many risk factors for suicide. I spoke with my supervisor regarding the case, who advised that I reach out to James and make every attempt to maintain contact with him. I called James on both of my days in the clinic, but to no avail. I left a message informing James that I would leave his usual time open the following week and that I very much hoped he would return.

When I returned to the clinic after the weekend, James had not called. I became more worried, and so in a final attempt to reach him, I called just an hour or so before his scheduled session. To my surprise, he answered, sounding groggy and tired. I told James I was very glad to have reached him, and asked if he would like to come in at his usual time. "Yeah," he replied, "I'll come."

James presented the next hour with deep bags under his eyes and moving slowly. James informed me that he had relapsed over the weekend and had drank a large bottle of vodka over the two days. "I know what you're gonna say," he told me, "I'm not supposed to drink, it's bad, blah blah blah." I told him that it was not my place to tell him what was good or bad for him, but that it did seem like he was in a rough spot and struggling mightily with something. James told me that he had bumped into an old friend of his from when he first moved to the city on the sidewalk outside his apartment building, who, to James' astonishment appeared not to remember him, callously brushing him off as if he "was a total stranger." James stated that he had become enraged, bought the bottle of vodka, and went back to his apartment. There, he had knocked over his kitchen table and had punched a wall, the dark purple bruises on his knuckle evident. "Wow," I told him, "I can't imagine how much that must've hurt you, to have an old friend brush you off 
The Effect of Integrating Music Listening With an Attachment- And Affective-Focused

Short-Term Psychotherapy in an Individual With Relational Trauma: The Case of "James" G.P. Blimling

Pragmatic Case Studies in Psychotherapy, http://pcsp.libraries.rutgers.edu

Volume 15, Module 2, Article 1, pp. 116-166, 07-10-19 [copyright by author]

like that." James was quiet for several moments, "Do you know Henry V?", he asked. "The play?", I responded. "No, I mean yes but the film, Lawrence Olivier." I told him that I was aware of it but not intricately familiar. "I watched it last night. There's this scene where Falstaff-you know Falstaff? Where he dies. I was so fucking angry all weekend, but when that scene came on, I just, I dunno, I started crying. I cried and cried, the music was like a punch in the stomach.”

In fact, I knew the music to which James was referring; Sir William Walton, a British composer, had written a well-known score to the film, and the music for the death of Falstaff was indeed very tragic and moving. "James, would it be ok if I played that music now?" James informed me that he did not have a copy of it, to which I responded we could use my computer that I had with me. I quickly found the selection, just shy of 3 minutes in length, and pressed play. We sat and listened together, James with his head in his hands. James soon began to sob uncontrollably, his tears dotting the linoleum floor.

This was the first time I had gotten a glimpse of the depth of James' true sadness, of his desperation. The music was the conduit by which his defenses had been bypassed, and instead of rage and condescension, he finally was able to feel what lay beneath, his core affect. It had returned him to that moment of despair he had felt while alone in his apartment, but this time he was able to let me see it. We sat in silence for several minutes following the conclusion of the movement. As James wiped his eyes, he quietly uttered just two words, "I'm alone."

I sat quietly and looked at James, but he did not raise his eyes from the floor. I said nothing for fear of disrupting this fragile moment, his experience of his core affect. Worse yet, I risked saying something that would cause him to return to his rageful, defended state. "There's nobody left - my sister is gone, her family wants nothing to do with me, not even an old friend wants anything to do with me." "I'm glad you came back," I said. James lifted his head and looked at me directly for the first time in the session. "Yeah, well.....you know....your job I guess," this time his contempt sounding more contrived than before. We were running out of time in the session, so I quickly did a risk assessment to ensure James was not experiencing suicidal or homicidal ideation, and I asked James if he thought he could make it to next week without drinking. "Yeah yeah, I know," he said. On his way out, he gave me a quick "Thanks, Doc," before disappearing down the hallway.

James would attend all four of the following sessions, which were utilized in the service of processing his experience following the incident with his old acquaintance and how it related more deeply to other experiences of rejection and loss. James discussed how the two had once worked together and would often socialize after work and on weekends, stating that they had become close when the individual took a job with another company and they grew apart. James stated that he had assumed his friend had been busy, and so was not overtly distressed at the distance that had grown between them.

However, given James' fragile state and the callousness with which he was spurned, James was able to identify that his reaction had been excessive and likely tied to "not feeling right" since the death of his sister. James would often assure me in the following sessions that he was "not having a breakdown" and that he "didn't normally cry like that." I was careful not to 
The Effect of Integrating Music Listening With an Attachment- And Affective-Focused

Short-Term Psychotherapy in an Individual With Relational Trauma: The Case of "James" G.P. Blimling

Pragmatic Case Studies in Psychotherapy, http://pcsp.libraries.rutgers.edu

Volume 15, Module 2, Article 1, pp. 116-166, 07-10-19 [copyright by author]

push James to return to that vulnerable state, but rather decided to allow the sessions to unfold at James' own pace.

\section{Sessions 13-20: American Pie-The End of Grief}

James was now attending sessions regularly, and while there continued to be instances of hostility towards me, our rapport had improved substantially following the most recent collaborative listening. James was able to smile and make jokes, many at his own expense, but the underlying sadness and isolation he felt were undeniably present.

Further, his anger, while somewhat more controlled than before, also continued to interfere with his functioning and his ability to access the more central sadness. In his more vulnerable moments, James had begun to focus on the centrality of his sister in his life. James would sometimes talk at length about her, depicting her as the only one who cared for him or tried to offer him any protection from his parents and the harsh realities of his world. "She was the only one who wanted me," he said. "Everybody else gave me the message that I wasn't wanted-my mom didn't care about anything but the next dollar or the next drink, and despite how hard I tried I could never make my dad love me. He was never around."

I sensed that we had begun to touch upon some significant aspects of James' history which were likely foundational to his current interpersonal difficulties. "How did she make you feel wanted?", I asked. James recounted how she would mail him care packages every so often, containing a variety of things - cookies, letters, drawings that she had made for him. "You know, she used to send me music, too. Old 45's with music she liked. She was given an allowance, so she had money to spend on those kinds of things, which I never did." I sensed this may have indicated an opening for James; it was clear that these things were tremendously meaningful to him, and were a significant source of ego strength which enabled him to tolerate the extreme interpersonal dysfunction that he encountered on a daily basis at home.

In session 16 James came in looking particularly chipper and carrying a cassette tape. "I have something to play for you," he announced before even finding his usual seat on my couch. James had been motivated by our conversations to search through some old belongings and discovered some items that his sister had sent to him back when he was young. "You might know this one," he said coyly, giving me an unusually genuine smile. I immediately put the cassette into the stereo and pressed play and heard Don McLean crackle over the speakers. "I recorded this off of my old record player," he declared. "Janice sent me the record in a package soon after it came out. Must've been 1971 or 1972. It was the neatest thing I had ever gotten in a package."

I was immediately struck by the effort James had put into bringing this tape- - he knew I had a computer and was capable of searching for music if he had asked, but instead he wanted to bring me the exact rendering he had received all those years ago. Furthermore, he had taken the time to rerecord onto the tape so as to bring something in himself, which to me reflected an investment in his therapy. "Thanks for bringing that, James," I said. "Sounds like this triggers some positive memories for you." James had a look on his face that I had not seen before, a sort 
The Effect of Integrating Music Listening With an Attachment- And Affective-Focused

Short-Term Psychotherapy in an Individual With Relational Trauma: The Case of "James" G.P. Blimling

Pragmatic Case Studies in Psychotherapy, http://pcsp.libraries.rutgers.edu

Volume 15, Module 2, Article 1, pp. 116-166, 07-10-19 [copyright by author]

of bittersweet nostalgic remembrance combined with that familiar sadness. "It came with a note that said, 'I hope this music can save your mortal soul,' I remember that,", James said, referencing the lyrics of the song. "She gave me so much, I don't think she even knew," James said, his eyes again becoming glassy. We sat in silence for several moments. "You know, I realize I avoided music for so long because of this feeling," he said. "What's the feeling?", I asked. "I can't really describe it. The song seems both happy and sad at the same time, and I don't know whether to smile or cry." I paused for a moment. "Janice did give you a lot. I'm glad you had someone to give that to you." James began to cry, this time without reservation. "I miss her so much," he said. Little was said for the rest of the session, I simply sat with James while he cried. "Can we play it once more?", he asked with about 10 minutes left. I rewound the tape, and this time James did not cry. When it was over he stood up with a slight smile on his face, shook my hand, and said "See you next week. Thanks doc."

\section{Sessions 21-28: Papaoute—Relational Trauma and Reparational Experience}

James presented to the next sessions looking much better. He was on time, looked as though he were taking care of himself, and often greeted me with a joke or humorous anecdote from the week. He reported that his depressive symptoms were abating (and his scores likewise substantiated this) and that he found himself more motivated to leave his apartment and to try to positively engage with others when he was out in public. James had been a voracious reader in the past, but had stopped reading after his sister passed away. Without any sort of suggestion from me, James announced one day that he had joined a book club that had begun to be an important source of social support for him. Further, he found that he was more in control of his anger, and had not drank any sort of alcohol in weeks. James' ability to both acknowledge and regulate his emotions had improved substantially; however, James had begun to discuss his relationship with his parents in more detail, and while they were now both deceased, he found that his emotions towards them were still quite intense and destabilizing. I had seen a sort of "zooming out" of our therapeutic focus, moving from proximal to distal events. While the relatively recent death of his sister and resulting downward spiral had been the catalyst which had brought him to therapy, it was becoming apparent that childhood trauma was of central importance to understanding James' current emotional and interpersonal struggles.

One day James came into my office and abruptly asked, “Do you speak French?” I found myself caught off guard by this question and fumbled to give a composed response. James had not mentioned the death of his sister in several weeks, opting instead to speak in greater detail about the negligent carelessness of his mother and the distant indifference of his father, and I was unsure how the question was related to our work together. "It's ok, I'll help you," James said with a wry smile as he handed me an unlabeled CD. "What's this?", I asked. "I don't really like it, but the lyrics caught my attention," James said. I inserted the CD into the stereo and pressed play, and after a brief introduction I heard a man singing in French. "You're giving me a run for my money today, I see," I said to James, who in turn smiled wider than I had yet seen him smile. James had been increasingly able to access more positive affect in session, and good-natured joking was a common bridge into more difficult therapeutic territory. "Can you figure out what it's about?", he asked. I responded that I would rather him tell me what the song was about. "It's called "Papaoute," it means "Where are you Dad?" Roughly, anyway. The French is kind of 
The Effect of Integrating Music Listening With an Attachment- And Affective-Focused

Short-Term Psychotherapy in an Individual With Relational Trauma: The Case of "James" G.P. Blimling

Pragmatic Case Studies in Psychotherapy, http://pcsp.libraries.rutgers.edu

Volume 15, Module 2, Article 1, pp. 116-166, 07-10-19 [copyright by author]

slangy," James said. "Sounds relevant," I replied. "I asked myself that question every day as a kid...," James trailed off. "I just wanted my dad to come and get me, to take me away from my mother." James became somber. "I hate her. She ruined our family," he said, looking at the floor. I reflected that those were strong words, and that I imagined there were strong emotions underneath them as well.

James went on to tell me in the greatest detail yet of his tumultuous and harshly abusive relationship with his mother; his mother had been a severe alcoholic, and, James suspected, a prostitute. James told me about her volatility when she drank, which was nearly all the time; she had struck James on a number of occasions with household items, sometimes requiring medical attention, and further requiring James to lie about how he had sustained such injuries. James' mother had, on one occasion, when he was approximately 8 years old, struck him in the head with a metal spatula with such force that he began to bleed heavily. Following this, she accused James of having made her strike him, telling him that she would have a heart attack and it was his fault. "I cried, not for myself but for my mother. I must've done something awful, and now I was going to cause her to die. I was wiping away tears from my face, but all I could see on my hands was blood." James was eventually taken to the hospital and was told to tell the doctors that a model train had fallen from the top shelf in the closet and hit him, and he required five stiches to close the gash on his head. "I wondered, why didn't my dad come and take me out of here? Was he just going to leave me with this woman?" James looked up at me after recounting this story, "I’ve never spoken about this before with anyone," he said.

I asked James what it was like to finally speak about it, and to speak about it with me. James paused for several moments. "Good actually," he said, "I know it sounds weird, but I feel like a weight is being lifted from me. I don't feel so angry, and the sadness feels different." In order to more fully explore how his experience had changed in therapy, I asked him to speak more about the sadness. James said that he had always felt alone, and that his sadness was irrelevant and a sign of weakness. Further, he had always felt that he was on his own in most aspects of his life, and that his emotional problems were his alone to bear as both a child and as an adult. "It's like I was drowning before," he said, "and I didn't even know it. Now I still have to swim, and that's hard work, but there's not the same desperation in it, you know?"

I was impressed with James' metaphor, and more importantly was struck by his increased ability to tolerate his affect without becoming totally dysregulated or relying on defenses that distanced him from people. He was, at this moment, experiencing a sadness which was neither disavowed nor incapacitating. Further, his characteristic anger and primitive devaluation were conspicuously absent. With respect to Fosha's model, James was now able to experience distressing emotion without becoming overly defended in the presence of another person with whom he felt secure, respected, and safe. This was an experience that he had only previously had with his sister, and his ability to maintain his secure attachment to me while still effectively processing so much traumatic material was a tremendous prognostic indicator.

I told James I thought he had been doing excellent work, conceding that the issues we were discussing were no doubt very painful and difficult for him. I also communicated that I saw a different James from the one who had initially walked into my office; he had been so 
The Effect of Integrating Music Listening With an Attachment- And Affective-Focused

Short-Term Psychotherapy in an Individual With Relational Trauma: The Case of "James" G.P. Blimling

Pragmatic Case Studies in Psychotherapy, http://pcsp.libraries.rutgers.edu

Volume 15, Module 2, Article 1, pp. 116-166, 07-10-19 [copyright by author]

emotionally dysregulated that his anger was simmering just below the surface, so much so that anyone who dared get near him was likely to experience his venomous barbs. The loss of his sister, perhaps the only individual with whom he had ever felt truly safe, had precipitated a major depressive period which was so severely destructive that it had literally threatened his life.

What's more, James had come to understand the role of alcohol in his life and how he had used it to "numb out" and escape from distressing affects, and he was consciously and actively taking steps to connect with others in a healthy way and avoid relapse. As the session ended, James stated that he was looking forward to "figuring it all out" with regards to his relationship with his parents, saying that he finally realized he had to "let them go." As he left my office, he asked me if I liked the music he had brought in. "I'm glad you brought it," I said, "but to be honest it's not really my style." "Damn!", James exclaimed, "I thought that's what people your age listened to, I thought you might be able to add it to your playlist!" James smiled again as he turned to leave.

James' words were impactful for me, as they were personal on many levels. His exclamation that he had brought music that he genuinely hoped that I would like seemed to be an affirmation of the strength of our relationship and James' efforts to reach me as a person. More importantly, though, James' remark that he needed to let his parents go echoed the situation in our own relationship. James had been making tremendous strides, and while there was clearly so much in his past that merited examination in therapy, there simply was not time to do so. Indeed, inclusion in any short-term model requires a mutual ability to focus on a chief complaint, and to likewise pass over material that is deemed of lesser significance (Messer \& Warren, 1995). James had been able to process the death of his sister, to examine his relationship with his parents and its effect on him, and to work through transferential issues in the therapy itself. This constitutes the triangle of persons first utilized by Ezriel (Messer \& Warren, 1995) which was later expounded upon in the work of David Malan, and which is utilized by numerous authors writing about short term dynamic therapy. James had "connected the dots" between how his interpersonal relationships and interpersonal style were related, and fundamentally to the model of Fosha, was able to have a meaningful experience in connecting past with present, and present with the therapy itself.

However, despite the fact that we were making considerable therapeutic gains, time was running short - we had now met for a total of 28 sessions and I had only one month remaining in my time at the clinic. I had informed James at the outset of the temporary nature of my engagement there and of the short-term aim of our treatment. He was long aware of the ultimate ending date, but it had not been directly discussed. Now came the time to consolidate gains made and to provide James with an adaptive experience of separation and loss.

\section{Sessions 29-32: Pushin' On-Consolidating Gains, Healthy Separation, and Moving Forward}

James' presentation in the recent sessions had been quite good. With April beginning and the arrival of good weather, James reported that he had been spending more time outside of his apartment. He had told me that he regularly attended his book club, now a weekly staple, and 
The Effect of Integrating Music Listening With an Attachment- And Affective-Focused

Short-Term Psychotherapy in an Individual With Relational Trauma: The Case of "James" G.P. Blimling

Pragmatic Case Studies in Psychotherapy, http://pcsp.libraries.rutgers.edu

Volume 15, Module 2, Article 1, pp. 116-166, 07-10-19 [copyright by author]

that he would often sit in the park and read his book for the week. James reported that he had even begun casually dating a woman from his book club, and that the two had found common ground in their love of art and drama. "She loves Chekov!", he exclaimed to me at the beginning of session \#29. "Do you know Checkov? Of course you don't, you're too young for that stuff," he said with a grin.

I was impressed with James' levity, but I needed to again raise the issue of our termination. "James, I know I usually leave the session open for whatever you'd like to discuss, but today I have something I was hoping we could talk about." James' face turned serious, "Sure, I guess," he said. I told James that, including the present one, we had four sessions remaining until we would have to end. James stared blankly at me for a moment. "So you're just going to leave? Where are you going?" I reminded James that, as we had discussed in the beginning, my engagement at the clinic was only temporary and that I would be moving on to a different setting. "So, what, now that I'm feeling better you're just going to leave?" I told James that it was something that had been decided even before we had begun therapy, and that I had enjoyed getting to know him and was genuinely happy to see him feeling so much better. "No, save it," James snarled. "I knew it. I knew from the beginning you were going to pull some shit like this. You know what, thanks for everything but I think we're done now actually." James stood up, and without making further eye contact walked past me and out the door.

I had suspected that the looming termination would be difficult for James; he had sat in my office for months and worked through issues of neglect, rejection, isolation, and loss. The intensity of his reaction, however, caught me by surprise, and I worried that our last sessions would end up looking very much like our first. His signal anxiety and fear of abandonment at my leaving had triggered well-worn and deeply embedded defense mechanisms, and his familiar indignant rage had returned. I remained in my office after James left and was surprised to receive a phone call from him approximately 45 minutes later. "I'm sorry," he said. "I've cooled off and I didn't mean to snap at you. I am mad that you're leaving, you should've told me sooner." I told James I was glad he had called, and that I hoped we could talk about how he was feeling at our next appointment. James requested to come in the following day, which I declined, as it was not a day I was at the clinic and because I wanted to maintain a secure frame for our remaining sessions. I suspected this might also trigger James, but to my pleasant surprise he responded with a pleasant "Sure thing, doc," before hanging up.

James was right on time for the following session (\#30). As he sat down, James said "That was shitty of you to spring that leaving stuff last time, but I know how you can make it up to me," this time with a slight smile. "You kept asking me for music...", I politely interrupted James to tell him that I had only "asked him for music" once, and even then it was only an invitation. "Yeah, whatever," he said, "but I kept bringing you music, and before you leave I'd like you to bring me some music." I pondered James' words briefly before I responded. "Sure, that sounds fair. I'll bring you a tune next week, but in the meantime I want to talk about what happened last time." James nodded in agreement. "I was upset that you said you were leaving, it felt like you were jumping ship," he said. I conveyed that I understood James' anger, and wondered aloud if it had something to do with what we had been discussing all along. James told me that he had realized after returning home that he was not angry at my stating that I was 
The Effect of Integrating Music Listening With an Attachment- And Affective-Focused

Short-Term Psychotherapy in an Individual With Relational Trauma: The Case of "James" G.P. Blimling

Pragmatic Case Studies in Psychotherapy, http://pcsp.libraries.rutgers.edu

Volume 15, Module 2, Article 1, pp. 116-166, 07-10-19 [copyright by author]

leaving per se, but rather had felt an intense but diffuse feeling of loss that was all too familiar to him. "It's not like it's that big a deal, I mean you're just my shrink," he clarified, "but it was kind of automatic."

I told James I was glad he had shared this with me, and that I thought he had done good work in therapy. James' ability to employ his observing ego and to reflect upon his emotions and behavior, including where they came from, was noticeably enhanced from when he had begun. Further, James' emotional experience was more varied and complex, and he was able to express himself more openly and honestly. This is not to say that his James' pathology had completely abated; he still carried very strong feelings regarding his parents and childhood abuse, as well as from the loss of his sister. Rather, James had broken through his own barriers to his core affect, and on each return trip its negative effects were diminished. James' "innate self-righting tendencies" (Fosha 2010) had begun to take hold, and while his work was not yet completed, he had made excellent progress.

As we the session drew to a close, James reminded me again to be sure to bring him some music as I had promised. I assured him I would, and he smiled and left.

I had many factors to consider in what music I chose to bring. I interpreted James' request as one for a sort of transitional object from the therapy, thus securing his sense of attachment before I left. I felt as though the music I chose should be personal, but not something that required too much self-disclosure or that removed the focus from James.

I decided on a tune called "Pushin' On," by the Quantic Soul Orchestra, which was a favorite of mine but also reflected relevant elements to our therapy as we concluded.

James showed up for the penultimate session right on time. "Did you bring it?," he asked. I told James that I had brought something to share with him, and asked if he would like me to play it then or if he would like to talk for a bit first. "No, you should play it now," he said. I opened my computer and put on the song and we listened together. "I kind of like that," James exclaimed when it was over, "I didn't peg you for a funk kind of person, though. How does it make you feel?" James asked, quasi-sarcastically. I told James that I did actually like funk music. "Sounds like that's not what you expected from me," I said. "I don't know, I guess I just thought you'd like more contemporary stuff. That's actually partially why I brought in that last song," he said, "because I guess I thought you might like it."

I was struck by James' assertion; he had chosen a song because he thought it would be something I liked, as well as something that was relevant for him. This demonstrated a willingness to connect that I found to be in stark contrast from James' initial presentation and overt disdain for me. His choice of music had become representative of his feelings of safety and attachment, and of wanting to relate and maintain proximity with me.

"Why did you ask me to bring in a song, James?" I asked. "I don't know, it just seemed fair since you always asked me to bring things," he said. "Fair enough," I responded, "but not everyone would have asked for that. I just wonder what it might mean for us as we wrap up." 
The Effect of Integrating Music Listening With an Attachment- And Affective-Focused

Short-Term Psychotherapy in an Individual With Relational Trauma: The Case of "James" G.P. Blimling

Pragmatic Case Studies in Psychotherapy, http://pcsp.libraries.rutgers.edu

Volume 15, Module 2, Article 1, pp. 116-166, 07-10-19 [copyright by author]

James thought for a moment and said, "I don't know, I guess I just wanted to know more about you. I only see you here and you never talk about yourself. I guess I just figured it was fair game to ask you." I noted that I did not think James would have made such a request, even just a few weeks ago. "Yeah, well, I guess you caught me there doc," he said. I told James I wasn't sure what he meant by that, to which he responded "Oh alright, I guess this was pretty good. You did better than I thought you would." I smiled and told James I appreciated the compliment. "How are you feeling as we come to the end?" I asked. "I'm thinking about what I'm going to do with all my free time now!" he said. "Maybe I'll take up parasailing or something," he joked.

I sensed James' levity in this instance as defensive; he seemed to be having trouble accessing, or at least articulating, the emotions that lay underneath his cheery exterior. I had come to understand the importance of our relationship; while he was able to begin to reconnect with others, I hypothesized that the loss of our relationship triggered anxiety about again being isolated and without a secure base to which to return. More importantly, James had grappled with his intense feelings of loss and grief, and the termination of therapy would represent yet another experience of loss for him. In keeping with Fosha's AEDP model, I felt it was important to maintain contact with those deep affects as we terminated in order for James to have a reparative experience regarding loss.

"You're joking, but something about you seems a little sad today James", I said. James paused and looked at the floor, as he often did when he began to feel sadness. "It's not like I'm going to have a breakdown or anything..." he trailed off. "Look, I guess I'm probably not the easiest guy to get along with, and I was pretty shitty to you in the beginning," he said. I asked James what he was trying to say to me. "I guess I wish you didn't have to go, but there's nothing to be done about it now is there." "Is there?" I asked. James sat quietly for a minute. "I think you picked that song for me, too. Just like I picked that one for you," he replied, now looking me in the eye again.

I was again impressed with James' perception. I had picked the song carefully, and it was true that it represented a hope for James to maintain the progress he had made and continue to move forward without me. "I guess I did," I said, "So, what do you think?" James again took a moment. "Thanks, doc," he replied. I informed James that we were out of time for the week. James confirmed our appointment the following week with somewhat more urgency than usual. I assured James I would be there, and he disappeared down the hallway.

James was again right on time for our final session. "So, this is it then?", he asked as he found his usual seat on my couch. "Yeah, this is it," I replied, "How're you feeling about it?" "Better than I thought I would," he responded. I asked James how he had anticipated that he would feel. "I don't know, I guess angry. When you first told me I was furious, but I don't feel that way anymore. I still wish you weren't leaving, but life goes on I guess." I reflected to James that this was the first time I had asked him directly about his feelings, and he had answered genuinely. "Huh, I guess it was," he said. I told James that I had really enjoyed working with him, and that I thought he had made a lot of progress in our relatively short time together. I asked James for his thoughts on how our treatment had gone, and to tell me what he thought was different now. "It was good; I honestly didn't think it would last, to be totally honest," he said. 
The Effect of Integrating Music Listening With an Attachment- And Affective-Focused

Short-Term Psychotherapy in an Individual With Relational Trauma: The Case of "James" G.P. Blimling

Pragmatic Case Studies in Psychotherapy, http://pcsp.libraries.rutgers.edu

Volume 15, Module 2, Article 1, pp. 116-166, 07-10-19 [copyright by author]

"In the beginning I didn't want anything to do with you, and I think I tried my best to get you to feel the same way."

James' increased ability for self-reflection and insight were remarkable; he had acknowledged that his irritability and anger were defensive devices that he used to keep people at a distance. This spoke to the tremendous reparative potential of our therapy, which allowed him to experience a secure attachment and to weather the storm of his intense emotional experience. I reflected to James that I thought he was very insightful, and his ability to identify that he was trying to push me away would serve him well in future relationships with others.

'I don't think I had ever really dealt with Janice's death before this. To be honest, I really didn't think I needed to talk about it, or that talking about it would do any good. Talking about feelings never did much for me before, but there you have it I guess," James said.

I told James that I agreed with him, that he had not allowed himself to process the intense emotions he felt, and that he had been brave to face them. "I guess I didn't know how much was underneath all of that, the anger, the drinking," he said. I told James that I thought that the intensity of his emotions came from more than just losing his sister, that much of it was tied to his relationship with his parents as well. "I never talked about it until now," he said. "I just didn't see any need to bring all that stuff up. It was just life, and I had to deal with it." I told James that I thought he had made a great start on that work, but that there would likely be situations which would trigger his strong feelings surrounding loss in the future. I asked James what issues he foresaw that might arise after we ended. "I don't know; I mean I know it's in there. That time I stormed out of your office showed me that." "Which time?" I asked jokingly. James smiled, "I guess I'll just have to try to keep it in check." I told James that his acknowledgement of and willingness to look at his reactions showed me just how far he had come, and that I felt hopeful for him as he moved forward with his life. "Thanks doc. So I guess we're about out of time," he noted. "I guess we are," I replied. James stood up and shook my hand, giving me one final "Thanks doc" before leaving.

\section{THERAPY MONITORING AND USE OF FEEDBACK INFORMATION}

Throughout James' treatment, I received weekly individual supervision from a licensed, clinical psychologist. This included a thorough review of both progress and process notes, a review of symptoms and assessment for any diagnostic changes, monitoring safety and developing a safety plan, as well as discussion of transferential and countertransferential issues. In addition, I sought guidance from a weekly supervision group with Nancy McWilliams, PhD. The group consisted of approximately 6 advanced graduate students who presented cases on a rotating basis. James' case was presented twice over the course of this group, and feedback regarding multiple aspects of treatment was offered by both Dr. McWilliams and other group members.

While James was further administered the Depression Anxiety and Stress Scales (DASS) 
The Effect of Integrating Music Listening With an Attachment- And Affective-Focused

Short-Term Psychotherapy in an Individual With Relational Trauma: The Case of "James" G.P. Blimling

Pragmatic Case Studies in Psychotherapy, http://pcsp.libraries.rutgers.edu

Volume 15, Module 2, Article 1, pp. 116-166, 07-10-19 [copyright by author]

and the Outcome Questionnaire-45 (OQ-45) on a bimonthly basis, as per clinic policy, these were not overtly used in treatment. Rather, they served to corroborate James' subjective expressions of distress and to provide an added dimension of analysis. As discussed in Chapter VIII, these data from these measures aligned with James' subjective reports of symptom distress and provided further diagnostic and clinical evidence.

\section{CONCLUDING EVALUATION OF THE THERAPY'S PROCESS AND OUTCOME}

James' treatment had been at least moderately successful, as evidenced by subjective reports of treatment outcome as well as objective self-report measures. James had presented with significant clinical impairment and distress, and upon termination had reported a significant remission in depressive symptoms. This was seen to be the result of processing unresolved feelings regarding the loss of his sister and his traumatic experiences as a child. The observed therapeutic mechanism of change is consistent with Fosha's AEDP model, such that the formation of attachment and experience of core affect were seen as central to this improvement. The added component of collaborative music listening was seen as largely facilitative of this effect, in that it provided a secondary mode of affective communication that allowed for deeper, more genuine expression of affect that was difficult to achieve through verbal processing alone.

\section{Quantitative Results}

Table 1 presents James' DASS scores. James' raw score of 31 on the Depression scale puts him in the range of extremely severe depression (27-42) and 3.5 standard deviations above normal. At the same time, James' scores on the Anxiety and Stress scales placed him in the Moderate and Severe range, respectively. James' scores all ultimately declined over time; however, at no point did any scale on any measure score within the Normal range. Further, James showed a substantial spike in anxiety symptoms (1.5 SD) and stress symptoms (0.5 SD) from the first to second administrations of the measure. This was attributed to adjustment issues at the beginning of therapy and to acute stressors that occurred during this time. Following the second administration, substantial decreases were seen in depressive and anxious symptoms, with moderate decreases shown on the stress scale. This is thought to be partially attributable to positive changes in James' life, such as increased social contact and increased activity level, which may also have contributed to levels of stress.

Table 2 presents James' scores on the OQ-45. Again, James' scores all ultimately show a substantial decline by the conclusion of therapy with a spike during the second administration, however James' scores on the Interpersonal Relations subscale and the Social Role subscale both indicate continued clinical significance at the conclusion of treatment. James' total score and Symptom Distress score fell below the clinical threshold, indicating substantial improvement by the end of treatment. James' Total Score as well as his scores on the Symptom Distress and Interpersonal Relations scale all showed statistically reliable change; however his Social Role score did not. This is thought to be the result of particularly limited social involvement in the beginning, which would likely skew the initial score lower. 
The Effect of Integrating Music Listening With an Attachment- And Affective-Focused

Short-Term Psychotherapy in an Individual With Relational Trauma: The Case of "James" G.P. Blimling

Pragmatic Case Studies in Psychotherapy, http://pcsp.libraries.rutgers.edu

Volume 15, Module 2, Article 1, pp. 116-166, 07-10-19 [copyright by author]

Overall, scores indicated substantial improvement, but did not indicate complete remission of symptoms. A longer treatment and further outcome monitoring would be necessary to gather further prognostic data.

\section{Qualitative Results}

Qualitative data from James' treatment further substantiates a positive outcome of therapy. These data are comprised of therapist observations, statements by James, and observable changes in behavior that reflect an overall improvement in clinical presentation at the end of treatment. They are as follows:

- James reported and the therapist observed a marked reduction in frequency and intensity of anger, both within the therapy and outside. James reported that he was substantially more able to control his aggressive behavior and that instances of dysregulation were markedly shorter in duration than at the outset of therapy, as evidenced by the therapeutic rupture that occurred in session 28. Importantly, James further endorsed an increased understanding and insight into the origins and purpose of his anger, stating that he understood it to be defensive and that it functioned to maintain distance from others and helped him avoid intimate interpersonal relationships.

- James endorsed a subjective reduction in depressive symptoms, including low mood, fatigue, apathy, decreased appetite, insomnia, difficulty concentrating, and suicidal ideation. James continued to report transient symptoms at the end of treatment, but symptoms were diagnostically sub-threshold and would be considered in remission at the conclusion of therapy.

- James reported an increased feeling of connection with others and less tendency to isolate than previously. This was evidenced by James' engagement in his book club and romantic interest in one of its members. James further exhibited increased interest in meaningful dialogue with the therapist as therapy progressed.

- James had begun to process affect related to unresolved grief regarding the sudden death of his sister and the traumatic experiences within his family relationships. James reported that he felt less severely impacted by these experiences and that he felt he had attended to issues to which he had not allowed himself to attend prior to therapy.

- James had maintained a period of abstinence from alcohol for several months and reported a decreased urge to drink. Further, James endorsed an understanding of the function of alcohol in his life.

\section{Effects of Music on Treatment Outcome}

As noted early in this paper, research has shown music to have facilitative effects on attachment, recall of autobiographical memory, and the elicitation of affect. These were found, 
The Effect of Integrating Music Listening With an Attachment- And Affective-Focused

Short-Term Psychotherapy in an Individual With Relational Trauma: The Case of "James" G.P. Blimling

Pragmatic Case Studies in Psychotherapy, http://pcsp.libraries.rutgers.edu

Volume 15, Module 2, Article 1, pp. 116-166, 07-10-19 [copyright by author]

overall, to have contributed significantly to the present treatment in each instance of music inclusion over the course of the therapy. While these constructs are fluid and interconnected, the following section will analyze the use of music in the different phases of treatment with regard to three of the areas that were substantiated earlier in the paper: attachment, memory, and elicitation of affect. Finally, the outcome will be discussed in relation to the stated hypotheses and guiding conceptualization.

\section{Sessions 1-4}

\section{$\underline{\text { Attachment }}$}

At the outset, James' hostile and defended disposition signaled a resistance to connecting with the therapist, or anyone else, as an attachment object. The initial choice of the Bill Withers song, "Lean on Me," was representative of early attachment that James had with his sister, and the resulting improvements on attendance and rapport were seen to be representative of the beginning of a transference of attachment to the therapist. The primitive nature of musical association inherent in the idea of "communicative musicality" (Malloch \& Trevarthen, 2002) was seen to facilitate the development of attachment to the therapist in the absence of meaningful verbal engagement at the outset of therapy. This is to say that the visceral shared experience of collaborative music listening allowed for James to bypass defensive structures that inhibited attachment formation. Further, the strong associations of the song to the attachment with his sister allowed for an accessing of those primitive needs for an attachment object.

\section{Memory}

With regard to its effect on autobiographical memory, the addition of collaborative music listening was also seen as substantially facilitative. Immediately after the listening and in the following week, James recalled numerous details about his early life and relationship with his sister, some of which he had not recalled prior to the instance of collaborative music listening. These details were specific in nature, including direct quotes and distinct interactions, which were in turn linked to strong affective experiences and responses. These types of memories and associations are consistent with the Music Evoked Autobiographical Memories as defined by Janata, Tomik, and Rakowski (2007) and discussed earlier.

\section{$\underline{\text { Affect }}$}

The elicitation of core affect was perhaps the most important contribution of collaborative music listening, both early in the treatment and throughout. James' initial defendedness and hostility made it extremely difficult to access these emotions through verbal processing alone. Attempts to access James' emotional experience in this way were almost entirely unsuccessful, as his defensive structures extremely rigid. This resulted in the predominance of his "signal affect," which manifested as anger and hostility. As such, the music was seen to have facilitated the bypassing of these defensive structures in just the sort of "right brain to right brain" type of communication referenced above by both Butterton and Fosha. This, conversely, provided the necessary basis for attachment formation and was seen to help establish 
The Effect of Integrating Music Listening With an Attachment- And Affective-Focused

Short-Term Psychotherapy in an Individual With Relational Trauma: The Case of "James" G.P. Blimling

Pragmatic Case Studies in Psychotherapy, http://pcsp.libraries.rutgers.edu

Volume 15, Module 2, Article 1, pp. 116-166, 07-10-19 [copyright by author]

some initial investment in the therapeutic process.

\section{Sessions 5-12}

The second instance of collaborative music listening, Walton's "Death of Falstaff," was somewhat different in that it was not planned prior to the session in which it was used and in that the music itself may not have been consciously chosen by James as part of the therapeutic process. Instead, the decision to utilize music was made spontaneously in the moment and after the client referenced an instance of core affective experience outside of the therapy that was related to a specific piece of music.

\section{$\underline{\text { Attachment }}$}

This second use of music within the therapy was seen to represent a turning point in the treatment, and its facilitation of strong attachment was seen as crucial to this change. James had reported reacted strongly to the music, which itself dealt thematically with death and loss, after having been spurned by someone with whom he had at one time been close. This was during a time of isolation for James already, and so the impact of this had been substantial. James' reaction was seen as the result of the experience of having no secure attachment objects in his life, and confronting the difficult emotions and intense vulnerability in therapy was seen to reinforce the attachment James felt to the therapist. This is to say that the therapist became a secure base for James and established the foundation for James to begin to regain emotional equilibrium and the ability to form new attachments outside of treatment. This, in turn, helped to reaffirm commitment to therapy, and James' attendance and engagement was substantially increased in the following sessions.

\section{Memory}

With regard to its impact on memory, the effects of this instance of music listening were somewhat more diffuse than in other instances, and thus seen as somewhat less important than other aspects. The music was not associated with a specific memory, but rather the themes of death, loss, isolation, and grief, which were all highly relevant to James' current situation. Rather than eliciting specific memories of important people or events, the music activated feelings associated with grief and loss, both with regard to the loss of an old friendship and, more importantly, the death of his sister.

\section{$\underline{\text { Affect }}$}

Again, however, the affective component of collaborative music listening was seen as the most important. James had reported substantially impairing affective experiences outside of therapy that had caused him to act out in self-destructive ways, including binge drinking, breaking objects in his apartment, and injuring his hand.

Following this, James reported having an intense emotional reaction to a piece of music outside of therapy which was reflective of his core affect, and so the ability to again access and 
The Effect of Integrating Music Listening With an Attachment- And Affective-Focused

Short-Term Psychotherapy in an Individual With Relational Trauma: The Case of "James" G.P. Blimling

Pragmatic Case Studies in Psychotherapy, http://pcsp.libraries.rutgers.edu

Volume 15, Module 2, Article 1, pp. 116-166, 07-10-19 [copyright by author]

productively process those emotions in therapy was highly desirable. The music was crucial in the elicitation of James' grief and sadness, and further it allowed him to do so quickly and deeply. These feelings, which had been at the center of James' considerable dysfunction and inability to connect with others, were accessed in full force, and this allowed for James' innate "self-righting tendencies" to begin to take hold. This was seen as perhaps the most important moment in the entire treatment, as it represented a breakthrough to James true, undefended state.

\section{Sessions 13-20}

Sessions 13-20 were seen as a period of marked improvement in James' clinical presentation. This period of therapy focused primarily on processing James' grief over losing his sister that had been accessed through the previous instance of collaborative music listening.

\section{$\underline{\text { Attachment }}$}

This period of therapy was characterized by a strong attachment to the therapist, which was evidenced through regular, punctual attendance and a more genuine relational style. James' experience of having been completely vulnerable and experiencing no negative repercussions from the therapist was seen as a key factor in this change. This is consistent with the focus of Fosha's AEDP model, which highlights the importance of genuine affective experience in a safe relationship as the foundation for emotional resilience and improvement in symptoms. This is not to say that James' symptoms had remitted, or that his had dispensed with his usual defensive patterns and signal affects; there continued to be instances of anger and hostility, however they were experienced as briefer and less intense by both therapist and patient.

Perhaps the most important indicator of this increased attachment was James' unilateral decision to bring in the next musical selection, “American Pie," by McLean. James' obvious pleasure in having brought it in of his own volition signaled that James felt invested in the therapeutic process and in the therapist. Further, his efforts to bring in an exact copy of the music he had received from his sister was again seen as a bridging of attachment; the recording was a sort of tangible representative of his attachment to his sister, and the act of physically bringing that object to share in therapy represented a transference of those feelings.

\section{Memory}

Again, James' choice of music carried with it salient memories which were relevant to the therapeutic work. Specifically, James recalled particular communications with his sister which were reflective of her care for him and her attempts to provide nurturance. The song itself originated from a particular period of vulnerability in James' life, and the memories were inextricably associated with his sister and her crucial role in his early life.

\section{$\underline{\text { Affect }}$}

Given that the processing of his sister's death appeared to be a primary objective of James' therapy and central to his emotional recovery, the use of music was again an enormously 
The Effect of Integrating Music Listening With an Attachment- And Affective-Focused

Short-Term Psychotherapy in an Individual With Relational Trauma: The Case of "James" G.P. Blimling

Pragmatic Case Studies in Psychotherapy, http://pcsp.libraries.rutgers.edu

Volume 15, Module 2, Article 1, pp. 116-166, 07-10-19 [copyright by author]

facilitative aspect in this stage of treatment. James demonstrated a much more subtle and differentiated range of affect than at any other time prior; whereas his affective life had consisted primarily of either rage or despondence, James now experienced the more emotionally reparative aspects of grieving the loss of his sister, including feeling nostalgia and gratitude. Further, James had demonstrated an ability to reflect upon his emotions rather than to be overwhelmed by them; his acting-out behaviors were beginning to be replaced by a more restrained and introspective stance, which had allowed James to engage more adaptively with others, not least of which was the therapist.

\section{Sessions 21-28}

This period of therapy was characterized by a shift in focus from the acute event of the death of James' sister to the more chronic emotional repercussions that resulted from James' neglectful and abusive childhood. In particular, James spoke about and processed angry feelings towards his mother and the pain that resulted from the absence of his father. As discussed in the case formulation, these were seen as a large part of James' difficulty in dependent relationships, as well as the reason anger was so predominant in James' presentation.

\section{$\underline{\text { Attachment }}$}

This period of therapy was characterized by a strong and stable attachment to the therapist. This was evidenced by James' relative disinhibition in verbalizing and expressing emotions, as well as the availability of positive affects such as humor within the therapeutic relationship. Further, James had begun to utilize this strong attachment to the therapist in a constructive way that reflected his ability to utilize the therapeutic relationship as a secure base, thus allowing him to venture out into the world and to form new attachments to others. This was evidenced by his engagement with his book club, his reportedly positive interactions with others in everyday situations, and in his ability to begin to explore the possibility of a romantic relationship.

James' choice of music, Stromae's "Papaoutai," was also seen as reflective of this strong attachment. James reported that he himself was not particularly moved by the song he had chosen to bring; however, he felt that the subject matter was relevant and, importantly, that the therapist might enjoy it. This was reflected in his suggestion that the therapist might "add it to [his] playlist," which was in direct contrast to James' resentment over just that issue at the outset of therapy. Further, while James' choice of music was reflective of somewhat "pathological" aspects of his personality, namely his highly intellectualized and somewhat narcissistic stance, these were expressed in more subtle and endearing ways than before. This is to say that James' choice of a song that was in French and not likely to be understood by the therapist, accompanied by the somewhat condescending assertion that he would "help" the therapist to understand demonstrated an overall consistency to James' character; but it also showed the more moderated expression of characteristics that had been problematic in the past. 
The Effect of Integrating Music Listening With an Attachment- And Affective-Focused

Short-Term Psychotherapy in an Individual With Relational Trauma: The Case of "James" G.P. Blimling

Pragmatic Case Studies in Psychotherapy, http://pcsp.libraries.rutgers.edu

Volume 15, Module 2, Article 1, pp. 116-166, 07-10-19 [copyright by author]

\section{Memory}

This choice of music was different in that it was contemporary, and thus not directly associated with any other time in James' life. Rather, the song was seen as a new association to the present. James did utilize the lyrics of the song as a sort of thematic starting point to discuss his relationship with his father, and by extension, his mother.

However, this was seen as somewhat superficial with regard to the elicitation of memory. Instead, this song was seen as an establishment of association to the present, and specifically to the therapist. It is likely that this song will remain highly associative to the time in therapy and relationship with the therapist beyond the actual termination of treatment. This is something that is hoped could be adaptive for James as he moves forward, and particularly as an associative tool should he experience a relapse into old ways of coping with difficult affect.

\section{$\underline{\text { Affect }}$}

As with memory, this selection seemed less relevant to affect associated with past events and more associated with affect in the present. James' admission that he did not care for the song demonstrated a lack of emotional connection to the music. Rather, this was seen as an attempt to connect emotionally with the therapist. James had utilized his choice of music in order to demonstrate his willingness to delve into emotionally activating material, but primarily James had chosen it as a sort of musical offering to the therapist. This reflected the ways in which musical selection had become a proxy for verbal expression of emotion, such that while it was likely for James to have significant difficulty directly expressing his feelings for the therapist, the presentation of music which he had hoped to be pleasing to the therapist indicated that he felt such emotions. Again, James' assertion that he had hoped the therapist would "add it to [his] playlist" was a metaphor for the overall emotionally reparative experience that had transpired over the course of therapy, especially given the use of that same phrase as derogatory in the outset of therapy.

\section{Sessions 29-32}

The focus of these sessions was on termination, and specifically on allowing James to have a reparative experience of loss. This was, of course, due to the theme of loss being of clinical relevance and primary focus throughout the therapy for James.

James' experiences of loss had been traumatic and emotionally destabilizing, and so from the outset of any short-term therapy, termination would be seen of primary importance and would need to be fully processed.

This period of therapy was marked by another unique feature, which was James' request for the therapist to choose music to be listened to in session (the Quantic Soul Orchestra's "Pushin' On"). This request was made directly following a brief rupture in the therapeutic alliance surrounding termination, but which also proved to be of clinical relevance and utility. 
The Effect of Integrating Music Listening With an Attachment- And Affective-Focused

Short-Term Psychotherapy in an Individual With Relational Trauma: The Case of "James" G.P. Blimling

Pragmatic Case Studies in Psychotherapy, http://pcsp.libraries.rutgers.edu

Volume 15, Module 2, Article 1, pp. 116-166, 07-10-19 [copyright by author]

\section{$\underline{\text { Attachment }}$}

Following the assertion that there remained only one month left in my time at the clinic, James had become enraged, stated that he was finished with therapy, and had left the session considerably early. This was interpreted as a regression into previous defensive reactions that were activated by the prospect of abandonment and loss. This was seen as representative of the strength of the attachment James felt to me, and that the powerlessness and dependence he felt in that moment were experienced as overwhelming. However, despite its similarities to previous situations which were experienced as similar, most notably the incident with James' old friend that had occurred near the beginning of treatment, James' reaction was substantially more brief and more easily examined and processed. This was evidenced by James' prompt follow-up and apology, and notably by his earnest expression of his genuine feelings; anger was present but not predominating James' experience, and he was able to look for and understand its legitimate source. In retrospect, I have come to agree with James that I should have raised the issue of termination sooner than I did given James' past and sensitivity to loss.

The following request for me to bring music was interpreted as a need for a sort of transferential object at the conclusion of treatment. It was also seen as a way of balancing the felt power dynamic, in that it was experienced as my choice when we ended, such that the feelings of powerlessness were counterbalanced by James' request for something in return. James was also able to express the meaning of his request, specifically that he felt he would like to know more about me. This was seen as a way of maintaining proximity and of establishing reciprocity in the relationship, namely for me to demonstrate to James that I cared for him as he did for me. It was clear that James was appreciative of my willingness to share something with him, and it was seen to contribute to a positive experience in the termination process.

\section{Memory}

As I would not discuss any personal memories associated with the song which I had brought as they would not be relevant to James' treatment, the function of memory was seen as grossly irrelevant in this instance where the roles were briefly reversed. This is to say that the use of music to evoke memory was seen as solely a process which would occur from the perspective of the patient. However, it should be noted that this use of music would likely serve as an associative stimulus for James in the future, and the hope would be that he could draw upon the song as being representative of the therapeutic experience the gains he had made.

\section{$\underline{\text { Affect }}$}

The use of music that I had chosen was seen to serve a different function than it had previously; rather than directly serving as an emotional stimulus, the utilization of music was seen as more symbolic. Any elicitation of affect from the song itself was seen as less relevant than the affect that resulted from the impending termination, the consolidation of gains, and the reciprocal fulfillment that were symbolized by it. This stood in contrast to the previous utilization of music to directly access difficult affect that were less accessible verbally. Instead, this use of music represented a sort of musical parting gift that capped off a largely successful 
The Effect of Integrating Music Listening With an Attachment- And Affective-Focused

Short-Term Psychotherapy in an Individual With Relational Trauma: The Case of "James" G.P. Blimling

Pragmatic Case Studies in Psychotherapy, http://pcsp.libraries.rutgers.edu

Volume 15, Module 2, Article 1, pp. 116-166, 07-10-19 [copyright by author]

course of treatment.

\section{Conclusion and Directions for Further Research}

The utilization of client-chosen music within the framework of Diana Fosha's Accelerated Experiential Dynamic Psychotherapy model was seen as largely effective in the case of James. This was observed to be in large part due to the ability of music to directly access underlying affect in session so that it could be processed. This is hypothesized to have been of particular benefit in this case, due to both James' strong resistance and his affinity for intellectual engagement. This is to say that James' intellectualized defenses and his innate appreciation for art may have contributed to the success of utilizing collaborative music-listening within Fosha's AEDP model, as this was a way of "rolling with" the defenses rather than pushing against them. More research is needed to further understand cases with which the addition of collaborative music-listening could be of benefit, including with differing diagnoses and personality types.

\section{REFERENCES}

Antony, M. M., Bieling, P. J., Cox, B. J., Enns, M. W., \& Swinson, R. P. (1998). Psychometric properties of the 42-item and 21-item versions of the Depression Anxiety Stress Scales in clinical groups and a community sample. Psychological Aassessment, 10(2), 176.

Blimling, G.P. (2015, October). The effect of integrating music listening with an attachment-and affective-focused short-term psychotherapy in an individual with relational trauma: The case of “James." Unpublished doctoral dissertation, Rutgers University, Piscataway, NJ.

Boer, D., Fischer, R., Strack, M., Bond, M. H., Lo, E., Lam, J. (2011). How shared preferences in music create bonds between people: values as the missing link. Personality and Social Psychology Bulletin, 37(9), 1159-1171.

Bowlby, J. (1982). Attachment and loss: Vol. 1. Attachment (2d ed.) New York: Basic Books.

Bruscia, K. E. (1998). The dynamics of music psychotherapy. Gilsum, NH: Barcelona Publishers.

Butterton, M. (2008). Listening to music in psychotherapy. Abingdon, UK: Radcliffe Publishing Ltd.

Fishman, D. (1999). The case for pragmatic psychology. New York: New York University Press.

Fosha, D. (2000). The transforming power of affect: A model for accelerated change. New York: Basic Books.

Fosha, D. (2010). Healing attachment trauma with attachment (... and then some!) In M. Klerman (Ed.)., Clinical pearls of wisdom: 21 leading therapists offer their key insights, pp. 43-56. New York: W.W. Norton \& Co.

Haver, P. V. (2013). Papaoutai. On Racine Carree [MP3 File]. Brussels, Belgium: Mosaert.

Holland, W. (2005). Pushin' On. On Pushin' On [MP3 File]. San Francisco, CA: Ubiquity Records.

Janata, P., Tomic, S.T., \& Rakowski, S.K. (2007). Characterisation of music-evoked autobiographical memories. Memory, 15(8), 845-860.

Juslin, P. N., \& Sloboda, J. A. (Eds.). (2010). Handbook of music and emotion. Oxford, UK: Oxford University Press.

Lambert, M. J., Burlingame, G. M., Umphress, V., Hansen, N. B., Vermeersch, D. A., Clouse, G. C., \& Yanchar, S.C. (1996). The reliability and validity of the outcome questionnaire. 
The Effect of Integrating Music Listening With an Attachment- And Affective-Focused

Clinical Psychology \& Psychotherapy, 4, 249-258.

Malloch, S., \& Trevarthen, C. (2010). Musicality: Communicative musicality: Exploring the basis of human companionship. New York: Oxford University Press.

McLean, D. (1971). American Pie. On American Pie [vinyl]. New York, NY: United Artists Records.

Messer, S.B. \& Warren, C.S. (1995). Models of brief psychodynamic therapy: A comparative approach. New York: Guilford.

Patel, A. D. (2010). Music, language, and the brain. New York, NY: Oxford University Press.

Sacks, O. (2007). Musicophilia: Tales of music and the brain. Toronto, CA: Alfred A. Knopf Inc.

Swallow, M. (2002). The brain - its music and its emotion: The neurology of trauma. In J.P. Sutton (Ed.), Music, music therapy and trauma: International perspectives. London, UK: Jessica Kingsley Publishers.

Trevarthen, C. \& Malloch, S. (2002). The musical lives of babies and families. Journal of Zero to Three, 23(1), 35-40.

Walton, W. (1963). Passacaglia: Death of Falstaff. On Henry V/Richard III/Spitfire [MP3 File]. London, UK. EMI Records.

Withers, Bill. (1972). Lean on Me. On Still Bill [Cassette Tape]. Los Angeles, CA: Sussex Records.

West, M. \& Sheldon-Keller, A. (1992). The assessment of dimensions relevant to adult reciprocal attachment. Canadian Journal of Psychiatry, 37(9): 600-6.

Wilson, G. D. (2002). Psychology for performing artists. London, UK: Whurr. 
The Effect of Integrating Music Listening With an Attachment- And Affective-Focused

Short-Term Psychotherapy in an Individual With Relational Trauma: The Case of "James" G.P. Blimling

Pragmatic Case Studies in Psychotherapy, http://pcsp.libraries.rutgers.edu

Volume 15, Module 2, Article 1, pp. 116-166, 07-10-19 [copyright by author]

Table 1

James' Scores: Depression, Anxiety, and Stress Scale

\begin{tabular}{|l|l|l|l|}
\hline Time & Depression & Anxiety & Stress \\
\hline October & $31(Z=3.5)^{* * * *}$ & $14(Z=2)^{* *}$ & $31(Z=2.5)^{* * *}$ \\
\hline December & $30(Z=3.5)^{* * * *}$ & $22(Z=3.5)^{* * * *}$ & $34(Z=3.0)^{* * * *}$ \\
\hline February & $19(Z=2.0)^{* *}$ & $12(Z=1.5)^{* *}$ & $27(Z=2.0)^{* * *}$ \\
\hline April & $13(Z=1.0)^{*}$ & $8(Z=0.75)^{*}$ & $20(Z=1.0)^{* *}$ \\
\hline
\end{tabular}

\footnotetext{
$* * * *$ Extremely Severe

$* * *$ Severe

** Moderate

* Mild
}

Table 2

James' Scores: Outcome Questionnaire - 45

\begin{tabular}{|l|c|c|l|l|}
\hline Time & Total Score & $\begin{array}{l}\text { Symptom } \\
\text { Distress Score }\end{array}$ & $\begin{array}{l}\text { Interpersonal } \\
\text { Relations } \\
\text { Score }\end{array}$ & $\begin{array}{l}\text { Social Role } \\
\text { Score }\end{array}$ \\
\hline October & 122 & 66 & 42 & 14 \\
\hline December & 119 & 63 & 39 & 17 \\
\hline February & 97 & 52 & 29 & 16 \\
\hline April & $57^{*}$ & $30^{*}$ & $15^{*}$ & $12^{*}$ \\
\hline
\end{tabular}

*Indicates score that falls at or below clinical threshold 
The Effect of Integrating Music Listening With an Attachment- And Affective-Focused G.P. Blimling

Pragmatic Case Studies in Psychotherapy, http://pcsp.libraries.rutgers.edu

Volume 15, Module 2, Article 1, pp. 116-166, 07-10-19 [copyright by author]

Table 3

Diagnosis at Beginning and End of Treatment

\begin{tabular}{|c|c|c|c|c|}
\hline & $\begin{array}{l}\text { DSM-I } \\
\text { of Ther }\end{array}$ & nosis at Beginning & $\begin{array}{l}\text { DSM-I } \\
\text { Therap }\end{array}$ & Diagnosis at End of \\
\hline Axis I & \begin{tabular}{|}
296.33 \\
305.00 \\
\end{tabular} & \begin{tabular}{|l|} 
Major Depressive \\
Disorder, Severe \\
w/o Psychotic \\
Features, \\
Recurrent \\
R/O Post \\
Traumatic Stress \\
Disorder \\
\\
Alcohol Abuse, \\
In Partial \\
Remission
\end{tabular} & $\begin{array}{r}296.36 \\
\\
305.00\end{array}$ & $\begin{array}{l}\text { Major Depressive } \\
\text { Disorder, Severe, In } \\
\text { Partial Remission } \\
\text { Alcohol Abuse, Early } \\
\text { Full Remission }\end{array}$ \\
\hline Axis II & 301.9 & $\begin{array}{l}\text { Personality } \\
\text { Disorder NOS; } \\
\text { R/O Borderline } \\
\text { Personality } \\
\text { Disorder; } \\
\text { R/O Narcissistic } \\
\text { Personality } \\
\text { Disorder }\end{array}$ & 301.9 & $\begin{array}{l}\text { Personality } \\
\text { Disorder, NOS }\end{array}$ \\
\hline Axis III & & $\begin{array}{l}\text { Atrial Fibrillation, } \\
\text { Hypertension }\end{array}$ & & $\begin{array}{l}\text { Atrial Fibrillation, } \\
\text { Hypertension }\end{array}$ \\
\hline Axis IV & & $\begin{array}{l}\text { Problems with } \\
\text { Primary Support } \\
\text { Group, Problems } \\
\text { Related to Social } \\
\text { Environment }\end{array}$ & & $\begin{array}{l}\text { Problems with } \\
\text { Primary Support } \\
\text { Group, Problems } \\
\text { Related to Social } \\
\text { Environment }\end{array}$ \\
\hline Axis V & & $\mathrm{GAF}=40$ & & $\mathrm{GAF}=70$ \\
\hline
\end{tabular}


The Effect of Integrating Music Listening With an Attachment- And Affective-Focused

Short-Term Psychotherapy in an Individual With Relational Trauma: The Case of "James"

G.P. Blimling

Pragmatic Case Studies in Psychotherapy, http://pcsp.libraries.rutgers.edu

Volume 15, Module 2, Article 1, pp. 116-166, 07-10-19 [copyright by author]

\section{APPENDIX}

NOTE: The five songs (lyrics below) that were part of the therapy are available on music sites like Spotify, and also available (with ads) on youtube.com, as follows:

Lean On Me (Withers)

https://www.youtube.com/watch?v=-59COFjB6Sk

Passacaglia: Death of Fallstaff (Walton; no lyrics)

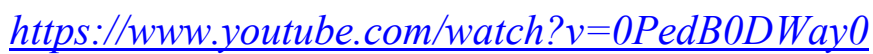

American Pie (McLean)

https://www.youtube.com/watch?v=uAsV5-Hv-7U

Papaoutai ("Stromae")

https://www.youtube.com/watch?v=MbR5EHHSfx4

Pushin' On (Quantic Soul Orchestra)

https://www.youtube.com/watch?v=wQkrAmjynnE 
The Effect of Integrating Music Listening With an Attachment- And Affective-Focused

Short-Term Psychotherapy in an Individual With Relational Trauma: The Case of "James"

G.P. Blimling

Pragmatic Case Studies in Psychotherapy, http://pcsp.libraries.rutgers.edu

Volume 15, Module 2, Article 1, pp. 116-166, 07-10-19 [copyright by author]

\section{Complete Song Lyrics}

\section{$\underline{\text { Lean On Me (Withers) }}$}

Sometimes in our lives

We all have pain

We all have sorrow

But if we are wise

We will realize there's

Always tomorrow

Lean on me, when you're not strong

And I'll be your friend

I'll help you carry on

For it won't be long

Till I'm gonna need

Somebody to lean on

Please swallow your pride If I have things

You need to borrow

For no one can fill

Those of your needs

That you won't let show

You just call on me brother

When you need a hand

We all need somebody to lean on

I just might have a problem

That you'll understand

We all need somebody to lean on

Lean on me, when you're not strong

And I'll be your friend

I'll help you carry on

For it won't be long

Till I'm gonna need

Somebody to lean on 
The Effect of Integrating Music Listening With an Attachment- And Affective-Focused

Short-Term Psychotherapy in an Individual With Relational Trauma: The Case of "James"

G.P. Blimling

Pragmatic Case Studies in Psychotherapy, http://pcsp.libraries.rutgers.edu

Volume 15, Module 2, Article 1, pp. 116-166, 07-10-19 [copyright by author]

You just call on me brother

When you need a hand

We all need somebody to lean on

I just might have a problem

That you'll understand

We all need somebody to lean on

If there is a load

You have to bear

That you can't carry

I'm right up the road

I'll share your load

If you just call me

Call me

If you need a friend 
The Effect of Integrating Music Listening With an Attachment- And Affective-Focused

Short-Term Psychotherapy in an Individual With Relational Trauma: The Case of "James"

G.P. Blimling

Pragmatic Case Studies in Psychotherapy, http://pcsp.libraries.rutgers.edu

Volume 15, Module 2, Article 1, pp. 116-166, 07-10-19 [copyright by author]

\section{American Pie (McLean)}

A long, long time ago

I can still remember how that music used to make me smile

And I knew if I had my chance

That I could make those people dance

And maybe they'd be happy for a while

But February made me shiver

With every paper I'd deliver

Bad news on the doorstep

I couldn't take one more step

I can't remember if I cried

When I read about his widowed bride

But something touched me deep inside

The day the music died

So bye, bye, Miss American Pie

Drove my Chevy to the levee but the levee was dry

And them good ole boys were drinking whiskey 'n rye

Singin' this'll be the day that I die

This'll be the day that I die

Did you write the book of love

And do you have faith in God above

If the Bible tells you so?

Now do you believe in rock and roll?

Can music save your mortal soul?

And can you teach me how to dance real slow?

Well, I know that you're in love with him

'Cause I saw you dancin' in the gym

You both kicked off your shoes

Man, I dig those rhythm and blues

I was a lonely teenage broncin' buck

With a pink carnation and a pickup truck

But I knew I was out of luck

The day the music died 
The Effect of Integrating Music Listening With an Attachment- And Affective-Focused

Short-Term Psychotherapy in an Individual With Relational Trauma: The Case of "James" G.P. Blimling

Pragmatic Case Studies in Psychotherapy, http://pcsp.libraries.rutgers.edu

Volume 15, Module 2, Article 1, pp. 116-166, 07-10-19 [copyright by author]

I started singing bye, bye, Miss American Pie

Drove my Chevy to the levee but the levee was dry

Them good ole boys were drinking whiskey 'n rye

Singin' this'll be the day that I die

This'll be the day that I die

Now for ten years we've been on our own

And moss grows fat on a rollin' stone

But that's not how it used to be

When the jester sang for the king and queen

In a coat he borrowed from James Dean

And a voice that came from you and me

Oh, and while the king was looking down

The jester stole his thorny crown

The courtroom was adjourned

No verdict was returned

And while Lenin read a book on Marx

The quartet practiced in the park

And we sang dirges in the dark

The day the music died

We were singing bye, bye, Miss American Pie

Drove my Chevy to the levee but the levee was dry

Them good ole boys were drinking whiskey 'n rye

Singin' this'll be the day that I die

This'll be the day that I die

Helter skelter in a summer swelter

The birds flew off with a fallout shelter

Eight miles high and falling fast

It landed foul on the grass

The players tried for a forward pass

With the jester on the sidelines in a cast

Now the halftime air was sweet perfume

While the sergeants played a marching tune

We all got up to dance

$\mathrm{Oh}$, but we never got the chance 
The Effect of Integrating Music Listening With an Attachment- And Affective-Focused

Pragmatic Case Studies in Psychotherapy, http://pcsp.libraries.rutgers.edu

Volume 15, Module 2, Article 1, pp. 116-166, 07-10-19 [copyright by author]

'Cause the players tried to take the field

The marching band refused to yield

Do you recall what was revealed

The day the music died?

We started singing bye, bye, Miss American Pie

Drove my Chevy to the levee but the levee was dry

Them good ole boys were drinking whiskey 'n rye

And singin' this'll be the day that I die

This'll be the day that I die

$\mathrm{Oh}$, and there we were all in one place

A generation lost in space

With no time left to start again

So come on, Jack be nimble, Jack be quick

Jack Flash sat on a candlestick

'Cause fire is the devil's only friend

Oh, and as I watched him on the stage

My hands were clenched in fists of rage

No angel born in Hell

Could break that Satan's spell

And as the flames climbed high into the night

To light the sacrificial rite

I saw Satan laughing with delight

The day the music died

He was singing bye, bye, Miss American Pie

Drove my Chevy to the levee but the levee was dry

Them good ole boys were drinking whiskey 'n rye

And singin' this'll be the day that I die

This'll be the day that I die

I met a girl who sang the blues

And I asked her for some happy news

But she just smiled and turned away

I went down to the sacred store

Where I'd heard the music years before

But the man there said the music wouldn't play

And in the streets, the children screamed

The lovers cried and the poets dreamed 
The Effect of Integrating Music Listening With an Attachment- And Affective-Focused

Short-Term Psychotherapy in an Individual With Relational Trauma: The Case of "James"

G.P. Blimling

Pragmatic Case Studies in Psychotherapy, http://pcsp.libraries.rutgers.edu

Volume 15, Module 2, Article 1, pp. 116-166, 07-10-19 [copyright by author]

But not a word was spoken

The church bells all were broken

And the three men I admire most

The Father, Son and the Holy Ghost

They caught the last train for the coast

The day the music died

And they were singing bye, bye, Miss American Pie

Drove my Chevy to the levee but the levee was dry

And them good ole boys were drinking whiskey 'n rye

Singin' this'll be the day that I die

This'll be the day that I die

They were singing bye, bye, Miss American Pie

Drove my Chevy to the levee but the levee was dry

Them good ole boys were drinking whiskey 'n rye

And singin' this'll be the day that I die 
The Effect of Integrating Music Listening With an Attachment- And Affective-Focused

Short-Term Psychotherapy in an Individual With Relational Trauma: The Case of "James"

G.P. Blimling

Pragmatic Case Studies in Psychotherapy, http://pcsp.libraries.rutgers.edu

Volume 15, Module 2, Article 1, pp. 116-166, 07-10-19 [copyright by author]

\section{$\underline{\text { Papaoutai (Stromae) }}$}

https://frenchcrazy.com/2014/10/papaoutai-english-translation-stromae.html/

What is this song about? ... The Belgian singer, Stromae, lost his father in the Rwanda genocide. The lyrics represent how he, as a young Belgian boy, wondered where his father was, and when he would return to be a present figure in Stromae's life.

\section{Dites-moi d'où il vient}

Tell me where he comes from

Enfin je saurais où je vais

Then I would know where I'm going

Maman dit que lorsqu'on cherche bien

Mommy says when you look hard enough

On finit toujours par trouver

You'll always end up finding it

Elle dit qu'il n'est jamais très loin

She says he's never very far away

Qu'il part très souvent travailler

He often leaves to go work

Maman dit « travailler c'est bien »

Mommy says "working is good"

Bien mieux qu'être mal accompagné, pas vrai ?

Better to be there than in bad company, right?

Où est ton papa ?

Where is your dad?

Dis-moi où est ton papa

Tell me where is your dad?

Sans même devoir lui parler

Without even having to talk to him

Il sait ce qui ne va pas

He knows what's wrong

Ah sacré papa

Oh my dear father

Dis-moi où es-tu caché ?

Tell me where are you hiding?

Ca doit faire au moins mille fois que j'ai compté mes doigts

I must've counted my fingers at least a thousand times

Où t'es papa où t'es ?

Where are you dad, where are you?

Où t'es papa où t'es?

Where are you dad, where are you? 
The Effect of Integrating Music Listening With an Attachment- And Affective-Focused

Short-Term Psychotherapy in an Individual With Relational Trauma: The Case of "James"

G.P. Blimling

Pragmatic Case Studies in Psychotherapy, http://pcsp.libraries.rutgers.edu

Volume 15, Module 2, Article 1, pp. 116-166, 07-10-19 [copyright by author]

Où t'es papa où t'es ?

Where are you dad, where are you?

Où t'es où t'es où papa, où t'es ?

Where are you, where are you, where are you dad, where are you?

Où t'es papa où t'es?

Where are you dad, where are you?

Où t'es papa où t'es?

Where are you dad, where are you?

Où t'es papa où t'es?

Where are you dad, where are you?

Où t'es où t'es où papa, où t'es ?

Where are you, where are you, where are you dad, where are you?

Quoi ? Qu'on y croie ou pas

What? Whether your believe or not

$Y$ aura bien un jour où on y croira plus

There will be a day when we no longer believe

Un jour ou l'autre on sera tous papa

On day or another we'll all be fathers

Et d'un jour à l'autre on aura disparu

And one day or another we'll all disappear

Serons-nous détestables?

Will we be hated?

Serons-nous admirables?

Will we be loved?

Des géniteurs ou des génies

Natural fathers or geniuses

Dites-nous qui donne naissance aux irresponsables

Tell us who gives birth to irresponsible [fathers]

Hein ? Dites-nous qui, tiens

Hey? Tell us who huh?

Tout le monde sait comment on fait des bébés

Everybody knows how to make babies

Mais personne sait comment on fait des papas

But nobody knows how to make dads

Monsieur « j'sais tout » en aurait hérité, c'est ça ?

Mister "know-it-all" would've inherited it, is that it?

Faut l'sucer de son pouce, ou quoi

Does it come from sucking our thumbs, or what

Dites-nous où c'est caché, ça doit, faire au moins mille fois qu'on a bouffé nos doigts

Tell us where it's hidden, we must've bit our nails a thousand times 
The Effect of Integrating Music Listening With an Attachment- And Affective-Focused

Short-Term Psychotherapy in an Individual With Relational Trauma: The Case of "James"

G.P. Blimling

Pragmatic Case Studies in Psychotherapy, http://pcsp.libraries.rutgers.edu

Volume 15, Module 2, Article 1, pp. 116-166, 07-10-19 [copyright by author]

Où t'es papa où t'es?

Where are you dad, where are you?

Où t'es papa où t'es?

Where are you dad, where are you?

Où t'es papa où t'es?

Where are you dad, where are you?

Où t'es où t'es où papa, où t'es ?

Where are you, where are you, where are you dad, where are you?

Où t'es papa où t'es?

Where are you dad, where are you?

Où t'es papa où t'es?

Where are you dad, where are you?

Où t'es papa où t'es?

Where are you dad, where are you?

Où t'es où t'es où papa, où t'es ?

Where are you, where are you, where are you dad, where are you?

Où est ton papa ?

Where is your dad?

Dis-moi où est ton papa

Tell me where is your dad?

Sans même devoir lui parler

Without even having to talk to him

Il sait ce qui ne va pas

He knows what's wrong

Ah sacré papa

Oh my dear* father

Dis-moi où es-tu caché ?

Tell me where are you hiding?

Ca doit faire au moins mille fois que j'ai compté mes doigts

I must've counted my fingers at least a thousand times

Où est ton papa ?

Where is your dad?

Dis-moi où est ton papa

Tell me where is your dad?

Sans même devoir lui parler

Without even having to talk to him

Il sait ce qui ne va pas

He knows what's wrong 
The Effect of Integrating Music Listening With an Attachment- And Affective-Focused

Short-Term Psychotherapy in an Individual With Relational Trauma: The Case of "James"

G.P. Blimling

Pragmatic Case Studies in Psychotherapy, http://pcsp.libraries.rutgers.edu

Volume 15, Module 2, Article 1, pp. 116-166, 07-10-19 [copyright by author]

Ah sacré papa

Oh my dear* father

Dis-moi où es-tu caché ?

Tell me where are you hiding?

Ca doit faire au moins mille fois que j'ai compté mes doigts

I must've counted my fingers at least a thousand times

Où t'es papa où t'es?

Where are you dad, where are you?

Où t'es papa où t'es?

Where are you dad, where are you?

Où t'es papa où t'es?

Where are you dad, where are you?

Où t'es où t'es où papa, où t'es ?

Where are you, where are you, where are you dad, where are you?

Où t'es papa où t'es ?

Where are you dad, where are you?

Où t'es papa où t'es?

Where are you dad, where are you?

Où t'es papa où t'es ?

Where are you dad, where are you?

Où t'es où t'es où papa, où t'es ?

Where are you, where are you, where are you dad, where are you? 
The Effect of Integrating Music Listening With an Attachment- And Affective-Focused

Short-Term Psychotherapy in an Individual With Relational Trauma: The Case of "James"

G.P. Blimling

Pragmatic Case Studies in Psychotherapy, http://pcsp.libraries.rutgers.edu

Volume 15, Module 2, Article 1, pp. 116-166, 07-10-19 [copyright by author]

\section{Pushin On (Quantic Soul Orchestra}

Till my stone cold grave I'll be Pushin on (she'll be pushing on)

Till my blood runs dry I'll be riding high (she'll be riding high)

When my soles wear through I won't be feeling blue, I'll be Pushin' on (pushin' on)

YEAH!

Till my soul fades by I've got to try try try (got to try try try)

Till my breath's all gone I'll be pushin' on so strong (oh so strong)

On Judgment day I won't fade away, I'll be Pushin' on (pushin on)

YEAH!

Till my dying day I won't give it all away I'll be pushin' on (pushin' on)

Till the rivers run dry I've got to try try try, I'll keep pushin' on (pushin' on)

When my soles wear through I won't be feeling blue, I'll keep pushin' on (pushin' on)

YEAH!

Push push pushin' on

She'll keep pushin' on

Push push pushin' on

She'll keep pushin' on

Push push pushin' on

She'll keep pushin' on

Push push pushin' on

She'll keep pushin' on

Push push pushin' on

She'll keep pushin' on

Push push pushin' on

She'll keep pushin' on

YEAH!

Push push pushin' on

She'll keep pushin' on

Push push pushin' on

She'll keep pushin' on 